OPEN ACCESS

Edited by:

Fabrizio Ceciliani,

University of Milan, Italy

Reviewed by:

Koumei Shirasuna,

Tokyo University of Agriculture, Japan

Gareth Healey,

Swansea University, United Kingdom

Mario Labéta,

Cardiff University, United Kingdom

${ }^{*}$ Correspondence:

Akio Miyamoto

akiomiya@obihiro.ac.jp

Specialty section:

This article was submitted to

Comparative Immunology,

a section of the journal

Frontiers in Immunology

Received: 20 October 2020 Accepted: 29 December 2020

Published: 11 February 2021

Citation:

Elesh IF, Marey MA, Zinnah MA, Akthar I, Kawai T, Naim F, Goda W,

Rawash ARA, Sasaki M, Shimada M and Miyamoto A (2021) Peptidoglycan

Switches Off the TLR2-Mediated

Sperm Recognition and Triggers

Sperm Localization

in the Bovine Endometrium.

Front. Immunol. 11:619408.

doi: 10.3389/fimmu.2020.619408

\section{Peptidoglycan Switches Off the TLR2-Mediated Sperm Recognition and Triggers Sperm Localization in the Bovine Endometrium}

\author{
Ibrahim Fouad Elesh ${ }^{1,2}$, Mohamed Ali Marey ${ }^{1,3}$, Mohammed Ali Zinnah ${ }^{1,4}$, Ihshan Akthar ${ }^{1}$, \\ Tomoko Kawai ${ }^{5}$, Fayrouz $\mathrm{Naim}^{6}$, Wael Goda ${ }^{2}$, Abdel Rahman A. Rawash ${ }^{2}$, \\ Motoki Sasaki ${ }^{7}$, Masayuki Shimada ${ }^{5}$ and Akio Miyamoto ${ }^{1 *}$ \\ 1 Global Agromedicine Research Center (GAMRC), Obihiro University of Agriculture and Veterinary Medicine, Obihiro, Japan, \\ ${ }^{2}$ Department of Pathology, Faculty of Veterinary Medicine, Damanhour University, Damanhour, Egypt, ${ }^{3}$ Department of \\ Theriogenology, Faculty of Veterinary Medicine, Damanhour University, Damanhour, Egypt, ${ }^{4}$ Department of Microbiology and \\ Public Health, Faculty of Veterinary Medicine and Animal Science, Bangabandhu Sheikh Mujibur Rahman Agricultural \\ University, Gazipur, Bangladesh, 5 Graduate School of Integrated Sciences for Life, Hiroshima University, Higashihiroshima, \\ Japan, ${ }^{6}$ Department of Microbiology, Faculty of Veterinary Medicine, Alexandria University, Alexandria, Egypt, ${ }^{7}$ Department \\ of Basic Veterinary Science, Obihiro University of Agriculture and Veterinary Medicine, Obihiro, Japan
}

In mammals, the uterine mucosal immune system simultaneously recognizes and reacts to most bacteria as well as allogenic sperm mainly through the Toll-like receptors (TLR)2/4 signaling pathway. Here, we characterized the impact of pathogen-derived TLR2/4 ligands (peptidoglycan (PGN)/lipopolysaccharide (LPS)) on the immune crosstalk of sperm with the bovine endometrial epithelium. The real-time PCR analysis showed that the presence of low levels of PGN, but not LPS, blocked the sperm-induced inflammatory responses in bovine endometrial epithelial cells (BEECs) in vitro. Immunoblotting analysis revealed that PGN prevented the sperm-induced phosphorylation of JNK in BEECs. Activation or blockade of the TLR2 system in the endometrial epithelium verified that TLR2 signaling acts as a commonly-shared pathway for PGN and sperm recognition. The impairment of endometrial sperm recognition, induced by PGN, subsequently inhibited sperm phagocytosis by polymorphonuclear neutrophils (PMNs). Moreover, using an ex vivo endometrial explant that more closely resembles those in vivo conditions, showed that sperm provoked a mild and reversible endometrial tissue injury and triggered PMN recruitment into uterine glands, while PGN inhibited these events. Of note, PGN markedly increased the sperm attachment to uterine glands, and relatively so in the surface epithelium. However, addition of the anti-CD44 antibody into a PGN-sperm-explant coculture completely blocked sperm attachment into glands and surface epithelia, indicating that the CD44 adhesion molecule is involved in the PGN-triggered sperm attachment to the endometrial epithelium. Together, these findings demonstrate that, the presence of PGN residues disrupts sperm immune recognition and prevents the physiological inflammation induced by sperm in the endometrial epithelium via the MyD88-dependent 
pathway of TLR2 signaling, possibly leading to impairment of uterine clearance and subsequent embryo receptivity.

Keywords: peptidoglycan, sperm, endometrium, toll-like receptor, cluster of differentiation 44

\section{INTRODUCTION}

In all mammals, the endometrial mucosa has a unique ability to deal with pathogens, allogeneic spermatozoa, and semi-allogeneic embryos (1-3). To achieve this, it seems likely that the uterus is equipped with an efficient and strictly controlled mucosal innate immune system that can differentially respond to these various antigens (4). Endometrial epithelia express highly conserved specific pattern recognition receptors (PRRs) that can recognize pathogens through pathogen-associated molecular patterns (PAMPs), and tissue injuries through damage-associated molecular patterns (DAMPs) (5). Among PRRs, Toll-like receptors (TLRs) efficiently recognize virtually all bacteria or their PAMPs, and mount an early immune response, resulting in the expression of inflammatory mediators (6). Consequently, immune cells (mainly polymorphonuclear cells, PMNs) are attracted to the site of infection, ensuring phagocytosis of invading microorganisms or cell fragments $(7,8)$. Identifying these early immunological mechanisms in the endometrium during pathophysiological conditions will be paramount for optimal fertility.

Specifically, bacterial peptidoglycan (PGN) is a lipopeptidepolymer forming most of the dry weight of G +ve (90\%) and G -ve (20\%) bacteria, while lipopolysaccharide (LPS) composes the remaining portion of the $\mathrm{G}$-ve bacterial cell wall and is a more potent endotoxin (9). LPS was detected in the blood and uterine fluid of cows with mild and severe endometritis (10), while no information is available about PGN levels in uterine lumen during clinical and subclinical endometritis in cows. Upon recognition, high levels of PGN/LPS activate the TLR2/4 pathway and trigger intracellular signal transduction cascades that stimulate deleterious effects on the host immune responses through the release of a potentially lethal array of inflammatory mediators (11). However, sustained low levels of PGN (LPS) could maintain chronic regulatory effects on the host immune balance, likely due to the secretion of anti-inflammatory cytokines $(12,13)$.

Mating or artificial insemination (AI) induces transient inflammatory reactions in the endometrium of several species and is characterized by the physiological influx of PMNs into the uterine lumen for clearance of bacteria, dead sperm and tissue debris (14). Like bacteria, sperm are phagocytized by PMNs either directly through cell-cell attachment or through neutrophil extracellular traps, which ensnare sperm and hinder their motility (15). Rapid removal of sperm is thought to prevent acquired immune responses against sperm in dams since it is critical for endometrial receptivity and pre-implantation embryo development (14). Our recent studies showed that active, but not heat-inactivated, sperm stimulated the transient mRNA expression of inflammatory genes in bovine endometrial epithelial cells (BEECs) (16) through triggering TLR2/4 signaling pathways (17) that increased PMN phagocytosis toward sperm in vitro (16). Moreover, in an ex vivo model, bovine sperm preferentially migrated to endometrial glands "sperm sensors" and initiated an inflammatory response associated with the presence of PMNs along with sperm (18).

Since the bovine endometrium recognizes PGN/LPS and sperm via the TLR2/4 pathways $(5,17)$, this study aimed to investigate competitive and pathophysiological interactions during co-exposure of the endometrial mucosa to sperm in the presence or absence of PGN/LPS. Our initial observations showed that only low levels of PGN, but not LPS, blocked sperm-induced inflammatory responses in BEECs in vitro. Moreover, recently it was reported that sperm interactions with the immunological defenses of the uterus were mediated mainly by the glandular epithelium (18). Accordingly, we used an ex vivo model of intact bovine endometrium explants to investigate the impact of very small quantities of PGN on the site and dynamics of sperm interactions with the uterine mucosa under conditions that more closely resemble those in vivo. To the best of our knowledge, this type of competitive crosstalk has not been described, and thus understanding its underlying mechanisms could have important translational implications in the context of reproductive mucosal immunology.

\section{MATERIALS AND METHODS}

\section{Ethical Approval}

The Committee of Animal Experiments at Obihiro University of Agriculture and Veterinary Medicine approved all experimental protocols and methods (permit no. 27-74).

\section{Experimental Design}

To describe the impact of pathogen-derived TLR2/4 ligands (PGN/LPS) on sperm-uterine immune crosstalk, we used both in vitro and ex vivo studies depicting possible various modes of exposure.

\section{In Vitro Study}

Initially, to investigate the competitive interaction of LPS/PGN and sperm with endometrial epithelium, subconfluent BEECs monolayers (90\%) were stimulated with PGN (LPS) at high (100 and $\left.1000 \mathrm{ng} \mathrm{ml}^{-1}\right)$ or low $\left(1,10\right.$, and $\left.100 \mathrm{pg} \mathrm{ml}^{-1}\right)$ concentrations for $24 \mathrm{~h}$, followed by co-culture with sperm $\left(5 \times 10^{6} \mathrm{ml}^{-1}\right)$ for $6 \mathrm{~h}$. Based on the results, more focus was given to the impact of low concentrations of PGN on sperm-induced inflammation in BEECs. To assess the direct BEECs response to PGN alone, BEECs were exposed to different concentrations of PGN in a time dependent manner. Moreover, sperm-triggered MAPKs cascade components were assessed following pre-exposure to 
PGN. For activation or blockage of the TLR2 pathway, a TLR2 agonist (pam3Cys) or antagonist (CU-CPT22) was used, respectively. Conditioned media (CM) from a sperm-BEECs co-culture, after pre-exposure to PGN, was harvested and exploited to challenge peripheral PMNs isolated from mature healthy cows. Subsequently, PMNs immune responses and phagocytic activity toward sperm were measured. Guided by our previous investigations (16-18), we evaluated the mRNA transcripts of TNFA, IL1B, IL8, PGES1, TLR2, and TLR4 as candidate inflammatory biomarkers throughout the entire study (Figure 1A).

\section{Ex Vivo Study}

The use of isolated BEECs monolayers may be compromised by the disruption of the endometrial architecture and by the release of DAMPs during tissue processing which may interfere with studying mechanisms of innate immunity and inflammation in the bovine endometrium (19). Therefore, an ex vivo model of intact bovine endometrium explants was also used to investigate the potential of PGN to affect the sites and dynamics of sperm interactions with the endometrial epithelium. Along with analyzing sperm-induced immune responses and changes in the architecture of endometrial tissues, a high-resolution 3D imaging microscopy was used to trace sperm dynamics and attachment after JC-1 mitochondrial illumination of their midpieces (Figure 1B).

\section{Uterine Sampling from Animals}

Healthy pre-ovulatory bovine uteri were grossly confirmed free of any pathological lesions during routine slaughterhouse work (16). Fresh samples from animals were immediately transferred to the laboratory and treated under strict aseptic conditions for cell and organ cultures.

\section{Sperm Processing for Co-Culture}

Semen straws were obtained from three highly fertile Holstein bulls belonging to Genetics Hokkaido Association, Hokkaido, Japan, where semen collection and processing were conducted under strictly controlled hygienic measures and the semen was routinely proven free from any bacterial contaminants. Semen straws were processed following a previously reported method (16). Briefly, nine straws (three straws from each bull) were thawed

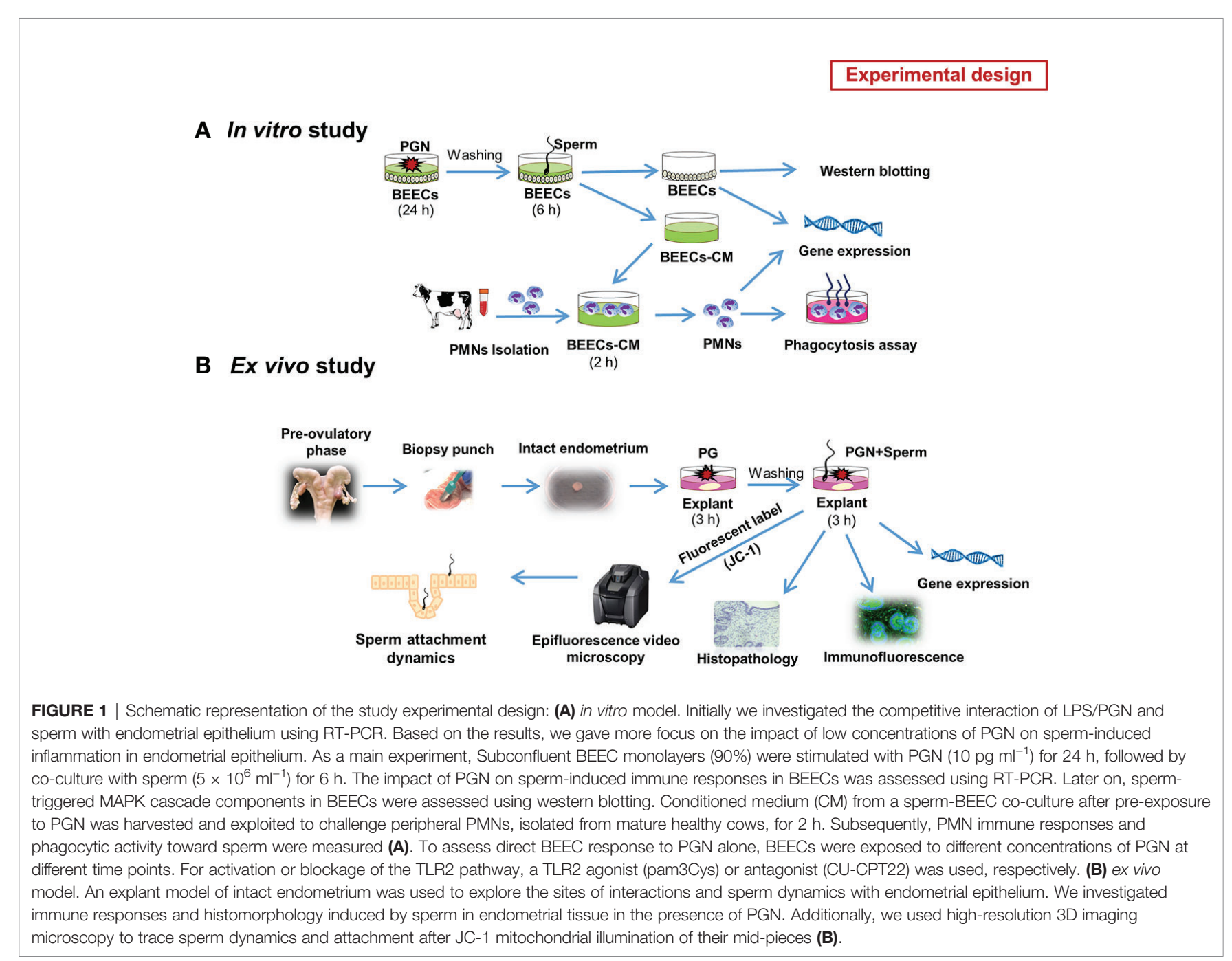


in a water bath at $38.5^{\circ} \mathrm{C}$ for $30 \mathrm{~s}$, pooled, and washed three times using a Tyrode's albumin, lactate, and pyruvate medium ( $\mathrm{Sp}$ TALP). A high-resolution 3D motion analysis of computer aided sperm analysis-sperm motility analysis system (CASA-SMAS) (DITECT, FHK, Tokyo, Japan) confirmed sperm motility $>70 \%$. In addition, the direct effect of natural and synthetic TLR2 agonists/antagonists on sperm motility was evaluated at different time points $(0,30,60$, and $120 \mathrm{~min})$. Washed sperm were used for co-culturing with BEECs or intact endometrial explants.

\section{BEECs Culture}

BEEC isolation and culture were performed according to a previously described protocol (16) with minor modifications. Cells were primed with pre-ovulatory levels of estradiol (E2) $\left(1 \mathrm{ng} \mathrm{ml}^{-1}\right)$ and progesterone (P4) (50 $\mathrm{pg} \mathrm{ml}^{-1}$ ) until reaching confluence. Confluence and intact integrity were determined using area fraction (AF) output based on cellular translucence and boundaries (ImageJ software Version1.51j8). Epithelial cell purity $>98 \%$ was evaluated using a monoclonal antibody against cytokeratin (anti-cytokeratin $8+18$; ab53280, Abcam, Tokyo, Japan). Optimal viability of Annexin V-labeled cells was confirmed by FACS (Cell Sorter SH800S, Sony Biotechnology Inc., Bothell, WA, USA). Vimentin-negative staining indicated the absence of stromal cell contamination. Moreover, FACS analysis confirmed the absence of immune cell contamination using RPhycoerythrin-conjugated mouse anti-CD45 hematopoietic cell marker (MA1-81458; Thermo Fisher Scientific, Waltham, MA).

\section{Pathogen-derived TLR2/4 Ligands}

Ultrapure polymeric PGN from G +ve Staphylococcus aureus (InvivoGen, San Diego, CA, USA) and LPS from G -ve Escherichia coli O55: B5 (Sigma-Aldrich) were used as natural TLR2 and TLR4 ligands5 respectively, for treatments and co-culture.

\section{Activation and Blockage of TLR2 Pathway}

For activation by the TLR2 agonist (17), subconfluent BEEC monolayers were pre-exposed to pam3Cys-Ser-(Lys) 4 , a synthetic analog of the triacylated N-terminal part of bacterial PGN (ab142085, Abcam) (10 pg ml ${ }^{-1}$ ), for $24 \mathrm{~h}$ followed by coculture with sperm for $6 \mathrm{~h}$. For blocking by the TLR2 antagonist (20), BEECs were pre-incubated with CU-CPT22, a synthetic TLR2 blocker (Merck, Darmstadt, Germany) (0.1 $\mu \mathrm{M}=36.24 \mathrm{ng}$ $\left.\mathrm{ml}^{-1}\right)$, for $3 \mathrm{~h}$ before being exposed to PGN $\left(10 \mathrm{pg} \mathrm{ml}^{-1}\right)$ for $24 \mathrm{~h}$ followed by co-culture with sperm for $6 \mathrm{~h}$.

\section{Real-Time PCR}

RNA was extracted from the cells using Trizol reagent (Invitrogen, Carlsbad, CA, USA) as previously reported (17). Extracted RNA was quantified using a NanoDrop Spectrophotometer 2000c (Thermo Scientific, Waltham, MA, USA), and the purity of each sample was assessed by the ratio A260/A280. The cDNA synthesis was done following the previously described protocol (21) with minor modifications. First, a DNase treatment step was performed using RQ1 RNase-Free DNase kit (Promega, Madison, WI, USA) to remove residual genomic DNA and other contaminants. The extracted RNA $(1 \mu \mathrm{g})$ was incubated for $30 \mathrm{~min}$ at $37^{\circ} \mathrm{C}$ in a thermal cycler (Eppendorf, Hamburg, Germany) with a first mixture consisting of $1 \mu \mathrm{l}$ of RQ1 RNase-free DNase 10× Reaction Buffer, $2 \mu \mathrm{l}$ of RQ1 RNase-free DNase (1 unit/ $\mu \mathrm{l}$ ), and Nuclease-free water (Invitrogen, Carlsbad, CA, USA) to a final volume of $10 \mu \mathrm{l}$ followed by addition of $1 \mu \mathrm{l}$ of the RQ1 DNase Stop solution for $10 \mathrm{~min}$ at $65^{\circ} \mathrm{C}$ to terminate the reaction. The first-strand cDNA was synthetized according to the commercial protocol described in the SuperScript ${ }^{\circledR}$ II Reverse Transcriptase kit (Invitrogen). Briefly, the DNase-treated RNA was incubated at $65^{\circ} \mathrm{C}$ for $5 \mathrm{~min}$ with a second mixture consisting of $1.5 \mu \mathrm{l}$ of $3 \mu \mathrm{g} /$ $\mu \mathrm{l}$ random primer, $1.5 \mu \mathrm{l}$ of $10 \mathrm{mM}$ PCR Nucleotide Mix (dNTP) (Roche Diagnostics, Indianapolis, IN, USA) and Nuclease-free water to a final volume of $18 \mu \mathrm{l}$. Next, a third mixture consisting of $6 \mu \mathrm{l}$ of $5 \times$ First-Strand Buffer, $3 \mu \mathrm{l}$ of $0.1 \mathrm{M}$ dithiothreitol, and 1.5 $\mu \mathrm{l}$ of 40 units/ $\mu$ l Ribonuclease Inhibitor Recombinant (Toyobo, Osaka, Japan), was added per each tube then, incubated at $42^{\circ} \mathrm{C}$ for $2 \mathrm{~min}$ followed by the addition of $0.2 \mu \mathrm{l}$ of $200 \mathrm{units} / \mu \mathrm{l}$ SuperScript ${ }^{\mathrm{TM}}$ II Reverse Transcriptase and the thermal cycler was programmed at $25^{\circ} \mathrm{C}$ for $10 \mathrm{~min}, 42^{\circ} \mathrm{C}$ for $50 \mathrm{~min}$, and $70^{\circ} \mathrm{C}$ for $15 \mathrm{~min}$. The synthesized cDNA was stored at $-30^{\circ} \mathrm{C}$. The mRNA expression levels of our selected genes were determined by a quantitative real-time polymerase chain reaction (PCR) using an iQ5 real-time PCR detection system (Bio-Rad Laboratories, Tokyo, Japan). Simply, a total $10 \mu \mathrm{l}$ reaction mix consisting of 2 $\mu \mathrm{l} /$ sample synthesized cDNA, $5 \mu \mathrm{l}$ of QuantiTect SYBR Green PCR Master Mix (QIAGEN, Hilden, Germany), $0.2 \mu \mathrm{l}$ of the targeted primer pairs (Supplementary Table 1), and $2.8 \mu \mathrm{l}$ nuclease-free water (Invitrogen) was prepared. Then, the amplification program was run with an initial denaturation step at $95^{\circ} \mathrm{C}$ for $15 \mathrm{~min}$, followed by 40 cycles of denaturation at $95^{\circ} \mathrm{C}$ for $15 \mathrm{sec}$, annealing at $51^{\circ} \mathrm{C}$ to $55^{\circ} \mathrm{C}$ (according to each primer) for $30 \mathrm{sec}$, extension at $72^{\circ} \mathrm{C}$ for $20 \mathrm{sec}$. The primers pairs were designed by Primer Express ${ }^{\circledR}$ Software v3.0.1 (Thermo Scientific). The calculated cycle thresholds $(\mathrm{Ct})$ were exported to Microsoft ${ }^{\circledR}$ Office Excel, normalized using ACTB ( $\beta$-actin) as a housekeeping gene, and the delta-delta comparative threshold method was used to quantify the fold change between the samples (22). All reactions were triplicated. Each run included a negative control (NCT) reaction, a non-reverse transcribed RNA (NRT) control, and a minus reverse transcriptase (MRT) control.

\section{Immunoblotting}

BEECs were pre-exposed to PGN (10 $\left.\mathrm{pg} \mathrm{ml}^{-1}\right)$ for $24 \mathrm{~h}$ followed by coculture with sperm for $1 \mathrm{~h}$. Briefly, protein samples from lysed BEECs were extracted by SDS polyacrylamide gel (10\%) electrophoresis and blot probing following the antibody manufacturer's instructions. Nonspecific sites were blocked, and membranes were incubated with primary antibodies against target TLR2 downstream proteins triggered by sperm (17) (Supplementary Table 2). The bands' intensities were analyzed using a Gel-Pro Analyzer (Media Cybernetics, Rockville, MD, USA).

\section{PMNs Cultivation}

Mature PMNs from healthy animals were isolated as previously described (23). Propidium iodide (PI)-stained PMN viability was 
$99 \%$, and population purity was $>98 \%$ as assessed by FACS analysis. PMNs $\left(7.0 \times 10^{6}\right.$ cells $\left.\mathrm{ml}^{-1}\right)$ were incubated in the sperm-BEEC CM for $2 \mathrm{~h}$ for determining PMN gene expression of pro- and anti-inflammatory cytokines.

\section{PMN Phagocytosis Assay}

In vitro phagocytosis of sperm by $\mathrm{PMNs}$ challenged in spermBEEC CM was measured as detailed previously (23), with minor modifications. The rate of PMNs with engulfed sperm was regarded as the phagocytic index (PA). A count of 1000 PMNs with phagocytosed sperm was carried out independently by two observers.

\section{Ex Vivo Organ Explant Co-Culture}

Ex vivo organ explants of endometrium from pre-ovulatory uteri were cultured according to a previously detailed protocol (18, 19), with minor modifications. Fresh, intact endometrial explants were pre-exposed to PGN (10 $\mathrm{pg} \mathrm{ml}^{-1}$ ) for $3 \mathrm{~h}$ followed by coculture with sperm for $3 \mathrm{~h}$. Microscopically, examined explants maintained typical histomorphology and adequate tissue viability as confirmed using hematoxylin and eosin (H\&E) tissue sections (24) and the mRNA expression of apoptotic caspase 3 (25).

\section{Histopathology}

Fixed specimens were serially dehydrated with ethanol, cleared into xylene shifts, and paraffinized again at $65^{\circ} \mathrm{C}$ as part of the routine FFPE technique previously detailed (26). Sections ( $3 \mu \mathrm{m}$ thickness) from ex vivo organ explants of endometrium were stained H\&E. Semi-quantitative scoring of histomorphology alterations was conducted in a blinded way in 10 fields selected randomly from each slide for each animal as described previously (27).

\section{Immunostaining}

Immunostaining was used for assessment and site-specific localization of target inflammatory (TNFA) and signaling (TLR2) biomarker protein expression, as previously described (17), with minor modifications. Briefly, sections $(3 \mu \mathrm{m})$ were incubated with primary antibodies against each protein target (Supplementary Table 3). Negative (omitted primary antibody) and isotype-matched (isotype-IgG) tissue controls were compared to reveal non-specific binding and false-positive expression. A high-resolution 3D scanning system combined with an all-in-one fluorescence microscope (Keyence, BZ-X800, Osaka, Japan) was used to localize the distribution of TNFA and TLR2 proteins in the endometrial tissue. The BZ-X GFP (OP87763), BZ-X RED (OP-87765), and BZ-X DAPI (OP-87762) filters were set for green, red, and blue wavelengths, respectively. The mean fluorescence intensity (MFI) and integrated density (IntDen) analyses of arbitrarily selected fields were corrected into total cell fluorescence (CTCF) values after subtraction of background fluorescence for semi-quantitative scoring (28).

\section{Imaging of JC-1-labeled Sperm}

Ex vivo organ explants of the endometrium were pre-exposed to PGN/pam3Cys $\left(10 \mathrm{pg} \mathrm{ml}^{-1}\right.$ ) for $3 \mathrm{~h}$. Sperm were directly pre- incubated with the JC-1 mitochondrial stain (AdipoGen, San Diego, CA, USA) (at $6.4 \mu \mathrm{M}$ ) for $15 \mathrm{~min}$ for sperm labeling and visualization in explants (18). JC-1-labeled sperm $\left(5 \times 10^{6}\right)$ were co-cultured with PGN-exposed explants and sperm behavior and localization were traced within 5 to $30 \mathrm{~min}$. A fully-focused 3D high-resolution imaging using an all-in-one epifluorescence microscope (Osaka, Japan) equipped with a temperaturecontrolled thermal plate (TPi-SQX, Tokai Hit, Japan) was used to view the sperm dynamics and localization in explants. During recording, the focus was adjusted in order to visualize all sperm attached to the glands and surface epithelium. Videos recorded at 30 min were assessed for numbers of sperm localized in uterine glands and in surface epithelia using ImageJ software (Version 1.51j8) (18).

\section{Measuring Cluster of Differentiation 44 (CD44) mRNA Expression and Fluorescence Intensity in Bovine \\ Endometrium}

The RT-PCR assay was exploited to test the possibility of endometrial cells expressing the cellular adhesion molecule (CD44) in BEECs and explants. An immunofluorescence assay using rabbit polyclonal antiCD44 antibody (1:50, 15675-1-AP, Proteinintech, USA) (Supplementary Table 3) was used to confirm the accumulation of CD44, especially in endometrial glands.

\section{CD44 Blocking Assay}

Endometrial explants were exposed to the anti-CD44 neutralizing antibody (1:500) (28) for $3 \mathrm{~h}$, washed, exposed to PGN (10 pg $\mathrm{ml}^{-1}$ ) for $3 \mathrm{~h}$ and then co-cultured with JC-1-labeled sperm. Recorded videos within 30 min were analyzed for sperm numbers associated with glands and surface epithelium using ImageJ software. Similarly, BEECs were exposed to the anti-CD44 antibody for $3 \mathrm{~h}$, washed, exposed to PGN (10 $\left.\mathrm{pg} \mathrm{ml}^{-1}\right)$ for $24 \mathrm{~h}$, and then co-cultured with sperm for $6 \mathrm{~h}$ followed by the RTPCR assay for detection of tested genes.

\section{Statistics}

We designated the animal as the statistical unit, and data from at least three to four replicated experiments were presented as mean \pm SEM. GraphPad Prism 8.0 software (La Jolla, CA, USA) was used to analyze differences among groups by performing one-way analysis of variance (ANOVA) followed by Bonferroni's postcomparison test (>two groups) or two sample $t$-test (two groups) with significant differences at $\left({ }^{*} P<0.05,{ }^{* *} P<0.01\right.$, or $\left.{ }^{* * *} P<0.001\right)$.

\section{RESULTS}

\section{Low Concentrations of PGN, But Not LPS, Suppressed Sperm-induced Inflammatory Responses in BEECs}

To investigate the competitive interaction of PGN/LPS and sperm with endometrial epithelium, BEECs were exposed to PGN/LPS at high (100, and $1000 \mathrm{ng} \mathrm{ml}^{-1}$ ) or low concentrations 
$\left(1,10\right.$, and $\left.100 \mathrm{pg} \mathrm{ml}^{-1}\right)$ for $24 \mathrm{~h}$ followed by addition of sperm for further $6 \mathrm{~h}$. The results showed that co-culturing of sperm with BEECs increased the mRNA expression of inflammatory cytokines (TNFA and IL1B), inflammatory chemokine (IL8), and PGES1 in BEECs. Moreover, high concentrations of LPS, either independently or combined with sperm, significantly increased transcription levels of tested genes in BEECs compared to sperm only (Supplementary Figure 1A). Additionally, the pre-exposure of BEECs to low levels of LPS induced inflammatory responses in BEECs, but do not interfere with the subsequent sperm-induced inflammation in BEECs (Figure 2A). High concentrations of PGN increased transcription levels of the tested genes in BEECs (Supplementary Figure 1B). Nonetheless, low concentrations of PGN failed to trigger any significant inflammatory responses in BEECs (except for PGN $100 \mathrm{pg} \mathrm{ml}^{-1}$ ), they suppressed the sperminduced abundance of expressions of inflammatory genes in BEECs, and this effect was maximum at PGN (10 $\mathrm{pg} \mathrm{ml}^{-1}$ ) (Figure 2B).

\section{PGN-induced Immediate and Transient Inflammatory Responses in BEECs}

Here, we investigated the impact of direct exposure to PGN (10, 100 and $1000 \mathrm{pg} \mathrm{ml}^{-1}$ ) on kinetics of inflammation in BEECs at different time points $(0,1,3,6,12$ and $24 \mathrm{~h})$. The results showed that PGN, in a dose-dependent manner, started to upregulate levels of transcripts of the tested genes after $1 \mathrm{~h}$, then the response reached its peak at $3 \mathrm{~h}$, it started to subside after $6 \mathrm{~h}$, and completely subsided after 12 to $24 \mathrm{~h}$. Additionally, PGN consistently maintained high transcription levels of IL10 and TGFB1 genes at 1, 3, 6, $12 \mathrm{~h}$ and subsided at $24 \mathrm{~h}$ (Figure 3).

\section{PGN Blocked Sperm-triggered JNK Phosphorylation as a Downstream Target of the TLR2 Signal Transduction Cascade in BEECs}

Ligation of TLR4 receptors to their specific agonist stimulates two distinct pathways, MyD88-dependent pathway and TRIF-
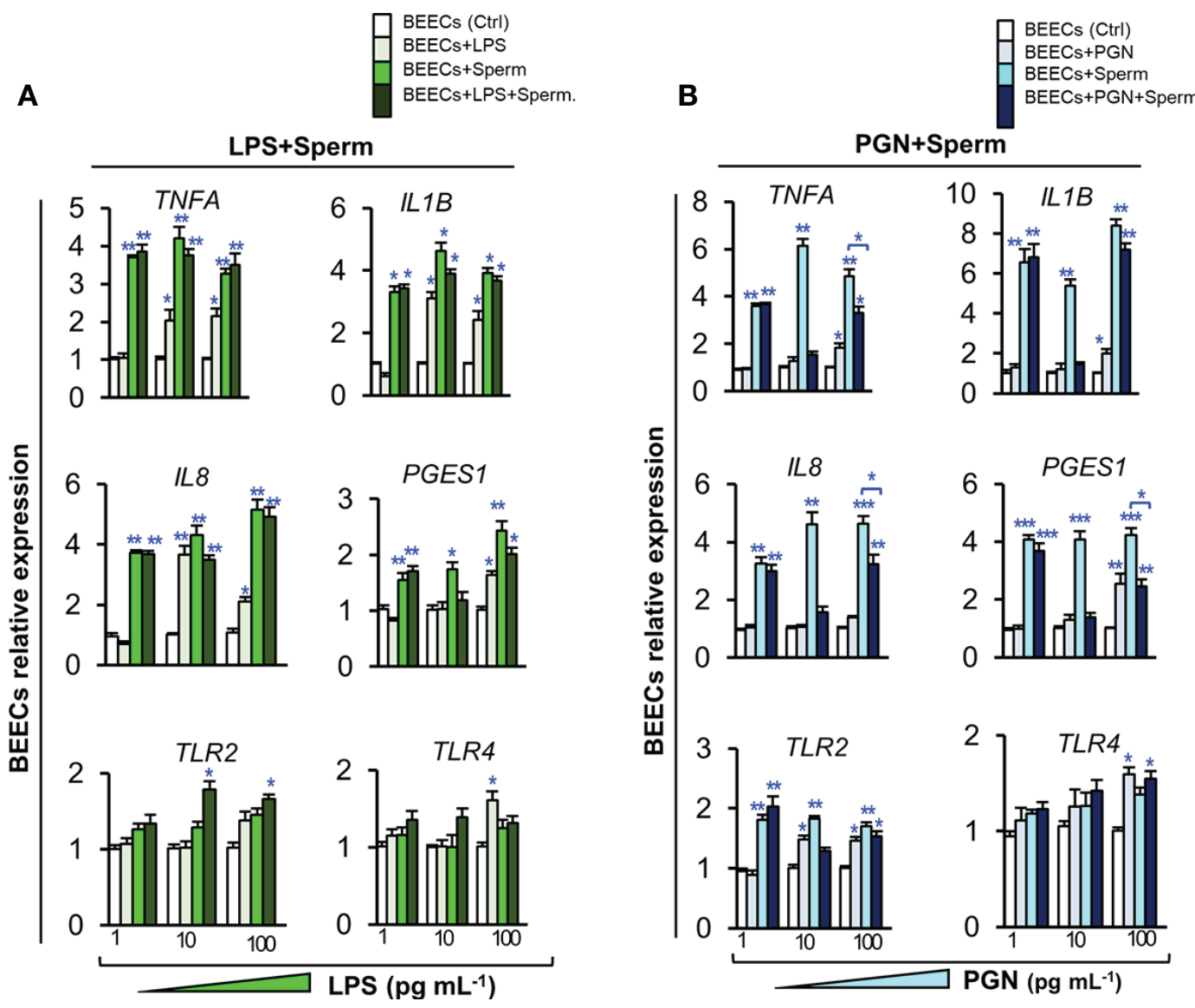

FIGURE 2 | Low levels of PGN, but not LPS, suppressed the stimulatory effect of sperm on the transcription of major inflammatory cytokines, chemokine, PGES1 and TLR2 in BEECs. Subconfluent BEEC monolayers were exposed to (A) LPS (1, 10, and $\left.100 \mathrm{pg} \mathrm{ml}^{-1}\right)$, or (B) PGN (1, 10, and $\left.100 \mathrm{pg} \mathrm{ml}{ }^{-1}\right)$ for $24 \mathrm{~h}$ followed by co-culturing with sperm $\left(5 \times 10^{6} \mathrm{cell} \mathrm{ml}^{-1}\right)$ for $6 \mathrm{~h}$. The mRNA transcription levels of major inflammatory genes (TNFA, IL1B, IL8, PGES1, TLR2, and TLR4) were quantified by real-time PCR assay. The animal was designated as the statistical unit, and the data was obtained from 3 replicated independent experiments, using BEECs from 3 different uteri, (3 wells/treatment/experiment) presented as mean \pm SEM. Asterisks denote a significant variance $\left({ }^{*} P<0.05{ }^{* *} P<0.01\right.$, or $\left.{ }^{* * *} P<0.001\right)$ between the different treatment groups when compared to the control group at each PGN/LPS concentration. Asterisk denotes a significant variance $\left({ }^{*} P<0.05\right)$ between the 'Sperm' and 'PGN+Sperm' groups. 


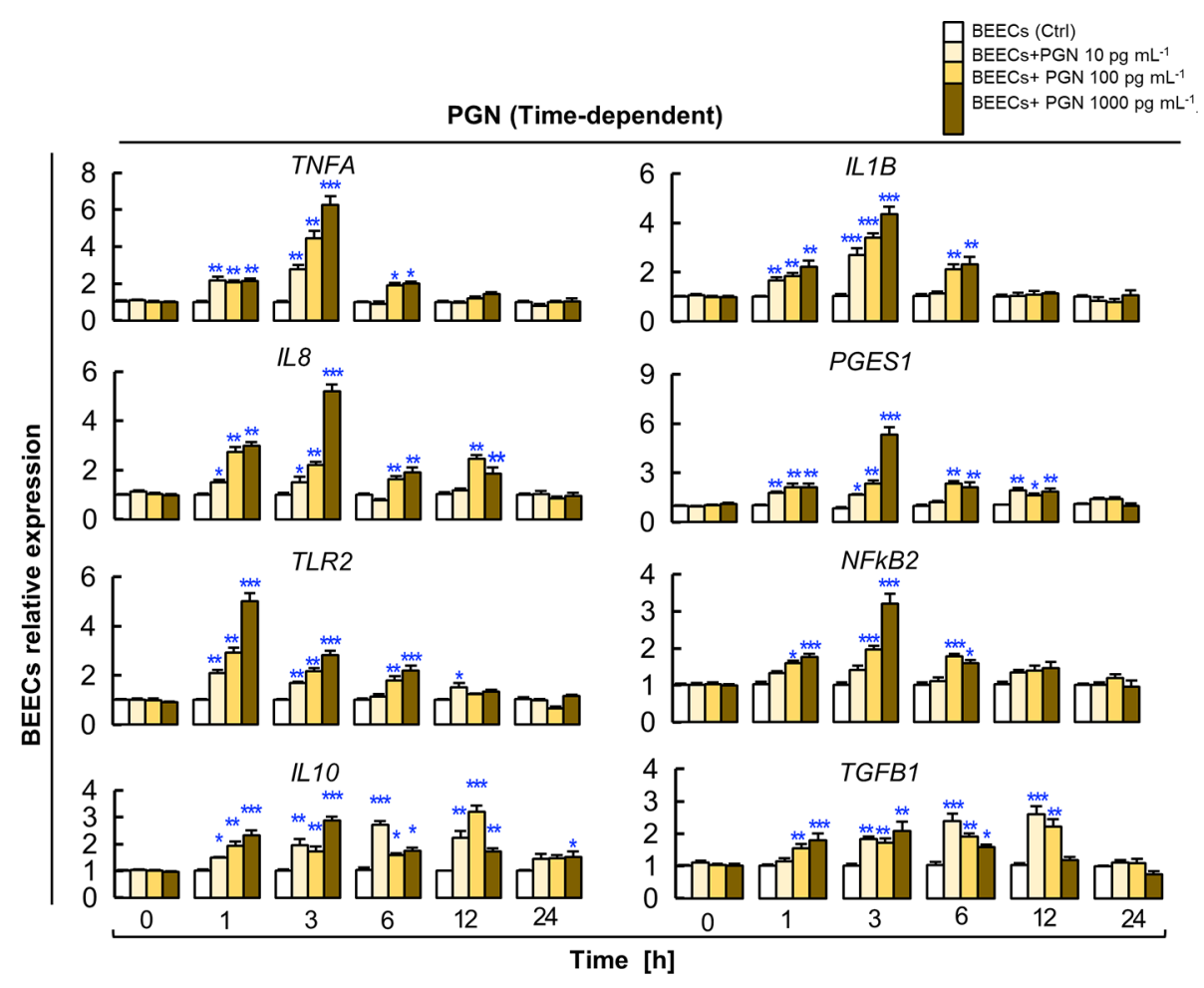

FIGURE 3 | PGN induces transient upregulation of the transcription of major pro- and anti-inflammatory markers in BEECs. Subconfluent BEEC monolayers were exposed to different picogram concentrations (10, 100 and $\left.1000 \mathrm{pg} \mathrm{ml}^{-1}\right)$ of PGN at different time points $(0,1,3,6,12$, and 24 h). The mRNA expression of major pro- and anti-inflammatory markers was assessed using RT-PCR assay. Data are presented as mean \pm SEM of 3 independent experiments using epithelial cells from 3 different uteri ( 3 wells/treatment/experiment). Asterisks denote a significant variance $\left({ }^{*} P<0.05^{* *} P<0.01\right.$, or $\left.{ }^{* * *} P<0.001\right)$ between the different groups of $P G N$ concentrations $(\mathrm{pg} / \mathrm{ml})$ when compared to the control group $(0 \mathrm{pg} / \mathrm{ml})$ at each time point.

dependent pathway while, ligation of TLR2 stimulates MyD88dependent pathway only (11). In our study, we focused on phosphorylation levels of p38MAPK, ERK1/2, and JNK as downstream targets of MyD88-dependent signaling pathways and IRF3 as downstream targets of TRIF-dependent signaling pathways. BEECs were pre-exposed to PGN (10 $\left.\mathrm{pg} \mathrm{ml}^{-1}\right)$ for $24 \mathrm{~h}$, washed, and followed by co-culturing with sperm for $1 \mathrm{~h}$. Then, we analyzed phosphorylation levels of p38MAPK, ERK1/ 2, JNK, and IRF3 as downstream targets of TLR2/4 signaling pathways triggered by sperm in BEECs (17). Immunoblotting analysis revealed that either PGN or sperm stimulated the phosphorylation levels of p38MAPK, ERK1/2, and JNK in BEECs, while PGN combined with sperm prevented the sperm-induced phosphorylation of the JNK component in BEECs. Neither sperm nor PGN stimulated the phosphorylation of the IRF3 in BEECs (Figure 4).

\section{Activating TLR2 Pathway Blocked the Sperm-induced Inflammatory Response in BEECs}

The above-mentioned results prompted us to propose that TLR2 signaling pathway is the common recognition system for PGN and sperm recognition in BEECs. To elucidate that, BEEC monolayers were exposed to synthetic TLR2 agonist (pam3Cys;
$10 \mathrm{pg} \mathrm{ml}^{-1}$ ) for $24 \mathrm{~h}$ followed by co-culturing with sperm for $6 \mathrm{~h}$. Pam3Cys fully blocked BEEC mRNA expressions of inflammatory mediators in response to sperm (Figure 5A) in a similar pattern to PGN, and this could further confirm that TLR2 is the central pathway for sperm recognition.

\section{Blocking the TLR2 Pathway Removed the PGN-Suppressive Effect on BEECs Inflammatory Responses to Sperm}

Likewise, we used a synthetic TLR2 antagonist (CU-CPT22) to block the TLR2 pathway in BEECs. BEEC monolayers were exposed to CU-CPT22 for $3 \mathrm{~h}$, washed, and exposed to PGN for $24 \mathrm{~h}$ before co-culturing with sperm for $6 \mathrm{~h}$. Interestingly, the TLR2 blocker recovered the sperm-triggered transcription of tested genes that was suppressed by PGN (Figure 5B). These findings could imply that TLR2 signaling could be a commonlyshared pathway for PGN and sperm recognition in BEECs.

\section{PGN Suppressed the Stimulatory Impact of Sperm-BEECs Conditioned Medium on PMN Gene Expression and Phagocytic Behavior}

Our previous studies have documented that sperm-BEEC CM upregulated PMN phagocytic activity towards sperm (16). 


\section{TLR2/ MAPKs signalling}

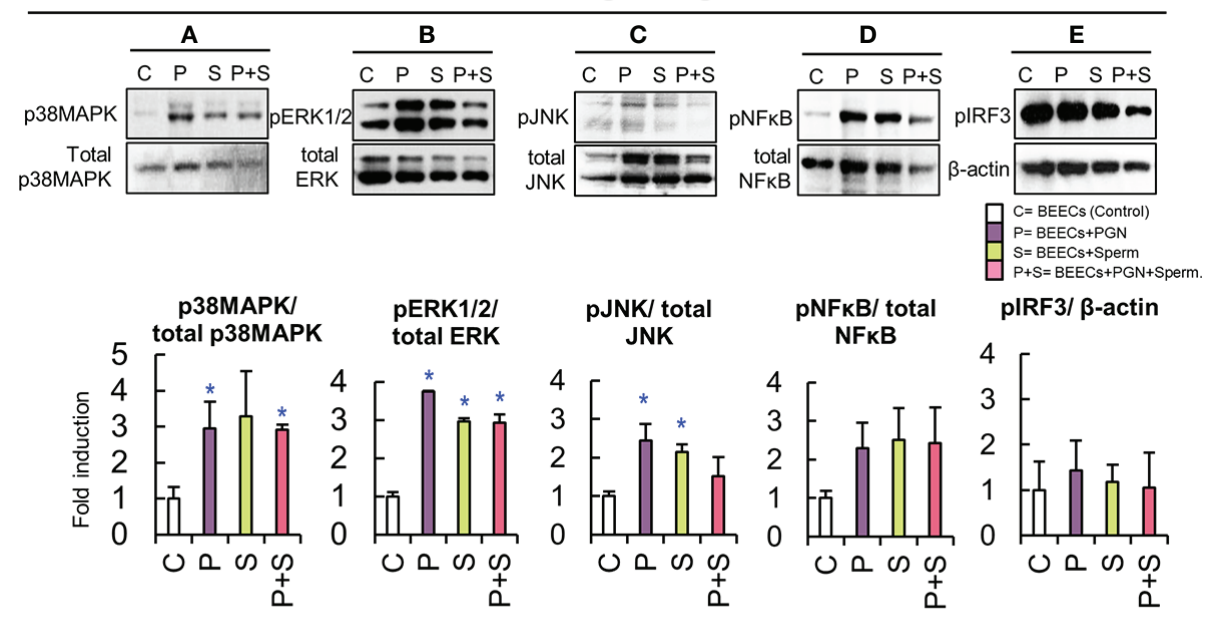

Endometrial epithelia

FIGURE 4 | PGN combination perturbed the sperm-triggered JNK phosphorylation in endometrial epithelia. Subconfluent BEECs monolayers were exposed to PGN $\left(10 \mathrm{pg} \mathrm{ml}^{-1}\right.$ ) for $24 \mathrm{~h}$ followed by co-culturing with sperm for $1 \mathrm{~h}$. Western blot analysis was carried out to estimate the phosphorylation levels of the mitogenactivated protein kinase (MAPK) cascade components in endometrial cells. Expression of specific antibodies against (A) P38 mitogen-activated protein kinase (p38MAPK), (B) phosphorylated extracellular signal-regulated kinase (pERK1/2), (C) c-Jun N-terminal kinase (JNK), (D) nuclear factor kappa-light-chain-enhancer of activated B cells (NF $K$ B), (E) phospho Interferon Regulatory Factor 3 (pIRF3) was assessed, and $\beta$ actin was used as a loading control in the different groups. The value under each sample indicates the fold change of the protein level relative to that of the control. The bands' intensity was analyzed using a Gel-Pro Analyzer (Media Cybernetics, Rockville, MD, USA). Data are presented as mean \pm SEM of 3 independent experiments using epithelial cells from 3 different uteri (3 wells/ treatment/experiment). Asterisks denote a significant variance $\left({ }^{*} P<0.05\right)$ between the different groups when compared to the control group.

Accordingly, in the current study, BEECs were exposed to PGN $\left(10 \mathrm{pg} \mathrm{ml}^{-1}\right)$ for $24 \mathrm{~h}$, washed, and co-cultured with sperm for $6 \mathrm{~h}$. Next, sperm-BEEC CM was used to stimulate peripherallyisolated mature PMNs for $2 \mathrm{~h}$ and then their inflammatory responses were evaluated. Also, these PMNs were cultured with sperm for $1 \mathrm{~h}$ as a phagocytosis assay. Cultivation of PMNs in sperm-BEEC CM sharply increased the expression of various proinflammatory genes and $C 3$ mRNA. However, pre-exposure to PGN blocked these responses and increased the expression of antiinflammatory genes (IL10 and TGFB1) in PMNs (Figure 6A). At the same time, PMN incubation in sperm-BEECs CM increased PMN phagocytic activity for sperm. Conversely, pre-exposure to PGN suppressed sperm phagocytosis by PMNs (Figures 6B, C). These results suggest that the endometrial secretome obtained from a PGN-sperm-BEEC co-culture could disrupt the innate immune responses of PMNs towards sperm.

\section{PGN Blocked Sperm-induced Inflammatory Responses in Endometrial Tissues Ex Vivo}

To further confirm our hypothesis, endometrial explants were exposed to PGN (10 $\mathrm{pg} \mathrm{ml}^{-1}$ ) for $3 \mathrm{~h}$ followed by co-culturing with sperm for $3 \mathrm{~h}$. The RT-PCR results showed that PGN suppressed the sperm-induced transcription of the tested genes in endometrial explants (Figure 7A). The immunofluorescence results showed that co-culturing of sperm with explants increased the mean fluorescence intensity (MFI) of expressed
TNFA and TLR2 proteins in the glandular epithelium (GE) and surface epithelium (SE). While, addition of PGN to the sperm-explant co-culture system abrogated MFI of TNFA and TLR2 proteins in these specific sites (Figures 7B-E). These findings further confirm a pivotal connection between endometrial responses to PGN and sperm, possibly through the TLR2 pathway.

\section{PGN Abrogated Sperm-induced Tissue Injury and PMN Recruitment Into Endometrial Glands}

Histomorphology of uterine explants revealed that sperm induced a mild degree of reversible tissue injury (epithelial degeneration) in the glandular epithelium and mucous membrane, with marked PMN infiltrations mainly in uterine glands. On the other hand, addition of PGN (10 $\mathrm{pg} \mathrm{ml}^{-1}$ ) to the sperm-explant co-culture system completely blocked sperm-induced alterations in the architecture of endometrial tissues (Figures 7F-H).

\section{PGN Increased Sperm Attachment to Endometrial Glands and Surface Epithelium}

To analyze sperm dynamics, ex vivo intact explants of endometrial tissue were exposed to PGN (0 or $10 \mathrm{pg} \mathrm{ml}^{-1}$ ) for $3 \mathrm{~h}$ followed by direct co-culture with JC-1-labeled sperm. As early as $5 \mathrm{~min}$, epifluorescence scanning microscopy revealed that vast numbers of spermatozoa clustered mainly in glands 


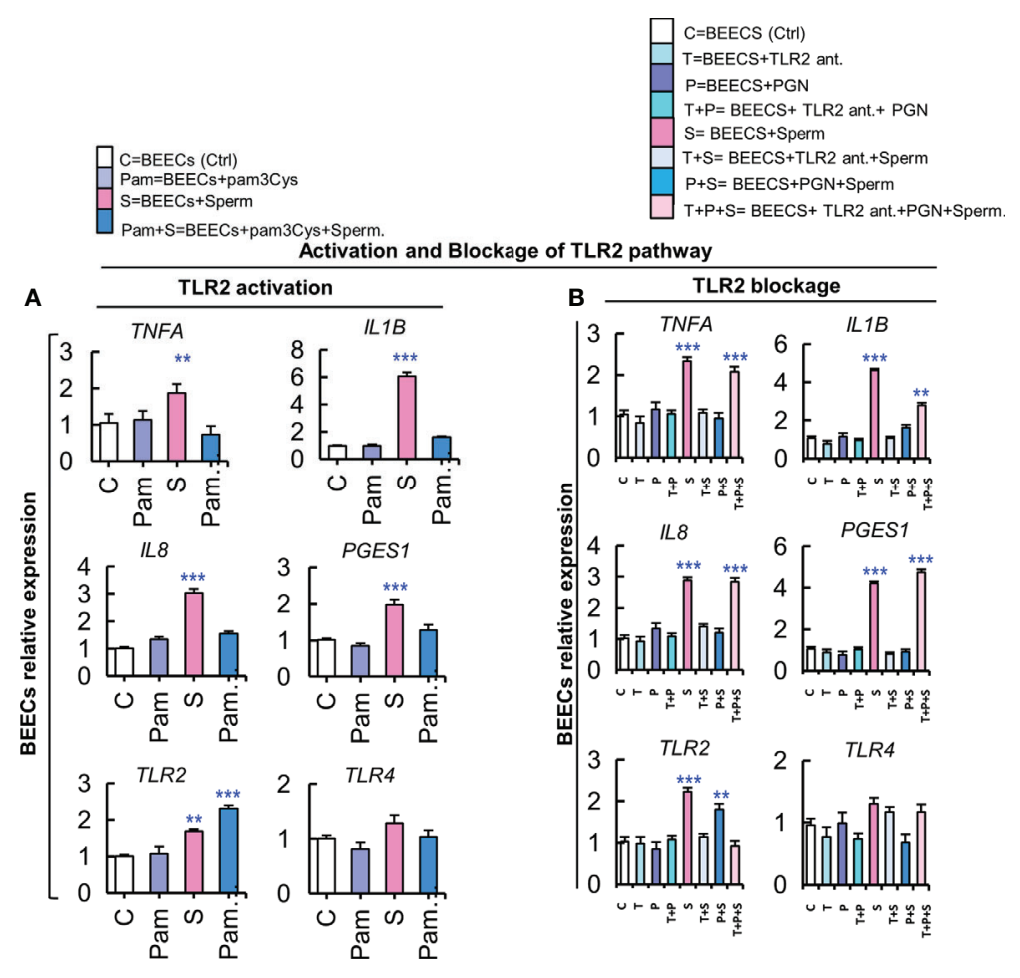

FIGURE 5 | Activation of the TLR2 pathway suppresses the stimulatory effect of sperm on transcription of inflammatory cytokines, while a TLR2 blockade removed the PGN suppressive effect on sperm-induced inflammation in BEECs. (A) BEECs activation with pam3Cys (synthetic TLR2 agonist). Subconfluent BEEC monolayers were exposed to pam3Cys $\left(10 \mathrm{pg} \mathrm{ml}^{-1}\right)$ for $24 \mathrm{~h}$ followed by co-culturing with sperm for $6 \mathrm{~h}$. (B) Blockage of TLR2 with synthetic TLR2 antagonist. BEECs were pre-exposed to CU-CPT22 $\left(0.1 \mu \mathrm{M}=36.24 \mathrm{ng} \mathrm{ml}^{-1}\right)$ for $3 \mathrm{~h}$ followed by exposure to PGN $\left(10 \mathrm{pg} \mathrm{ml}^{-1}\right)$ for $24 \mathrm{~h}$ before co-culturing with sperm for $6 \mathrm{~h}$. The mRNA expression of major inflammatory genes was assessed using RT-PCR assay. Data are presented as mean \pm SEM of 3 independent experiments using epithelial cells from 3 different uteri ( 3 wells/treatment/experiment). Asterisks denote a significant variance $\left({ }^{*} P<0.05{ }^{* *} P<0.01\right.$, or $\left.{ }^{* * *} P<0.001\right)$ between the different groups when compared to the control group.

with their flagella continuing to beat until after $30 \mathrm{~min}$. Preexposure to PGN markedly increased sperm localization in glands, and relatively so in the surface epithelium (Figure 8D, and Supplementary Video 1, 2). As well, treatment of explants with pam3Cys $\left(10 \mathrm{pg} \mathrm{ml}^{-1}\right)$ triggered sperm attachment to the endometrial epithelium (Supplementary Video 3).

\section{PGN Triggered Sperm Attachment to Endometrial Mucosa via Upregulation of Cluster of Differentiation 44 (CD44)}

We hypothesize that a CD44 adhesion molecule is involved in PGN-triggered sperm localization to endometrial glands and the surface epithelium. The RT-PCR assay revealed that the combination of PGN with sperm upregulated CD44 mRNA expression in both BEECs and explant models (Figure 8A). An immunofluorescence assay confirmed a corresponding increase in CD44 protein expression, especially in glands and surface epithelium (Figures 8B, C). Furthermore, addition of anti-CD44 neutralizing antibody minimized sperm attachment to these unique sites and sperm appeared freely moving on the surface epithelium (Figures 8D, E, and Supplementary Video 4). The results suggest that CD44 plays a principal role in PGN-triggered attachment of large numbers of sperm into the endometrial mucosa.

\section{DISCUSSION}

Mucosal surfaces of the female genital tract are the first line of defense against potentially pathogenic microorganisms. Indeed, the uterus is not a completely sterile cavity as it has been classically considered; recently the use of $16 \mathrm{~S}$ rRNA sequencing provides several lines of evidence that human endometrial mucosa is rich with a Lactobacillus-dominated microbiota (>90\% Lactobacillus spp.) and minor alterations in commensal uterine colonization could negatively interfere with local immunity, endometrial receptivity, and fertility (29-31). Our study provides evidence that the presence of traces of pathogen-derived PGN desensitized endometrial mucosa to recognize sperm and thereby preventing sperm-triggered immune responses in the endometrial epithelium mainly via the MyD88-dependent pathway of TLR2 signaling. Consequently, the inflammatory response and phagocytic activity of PMNs towards sperm were blocked. Moreover, PGN intensively 

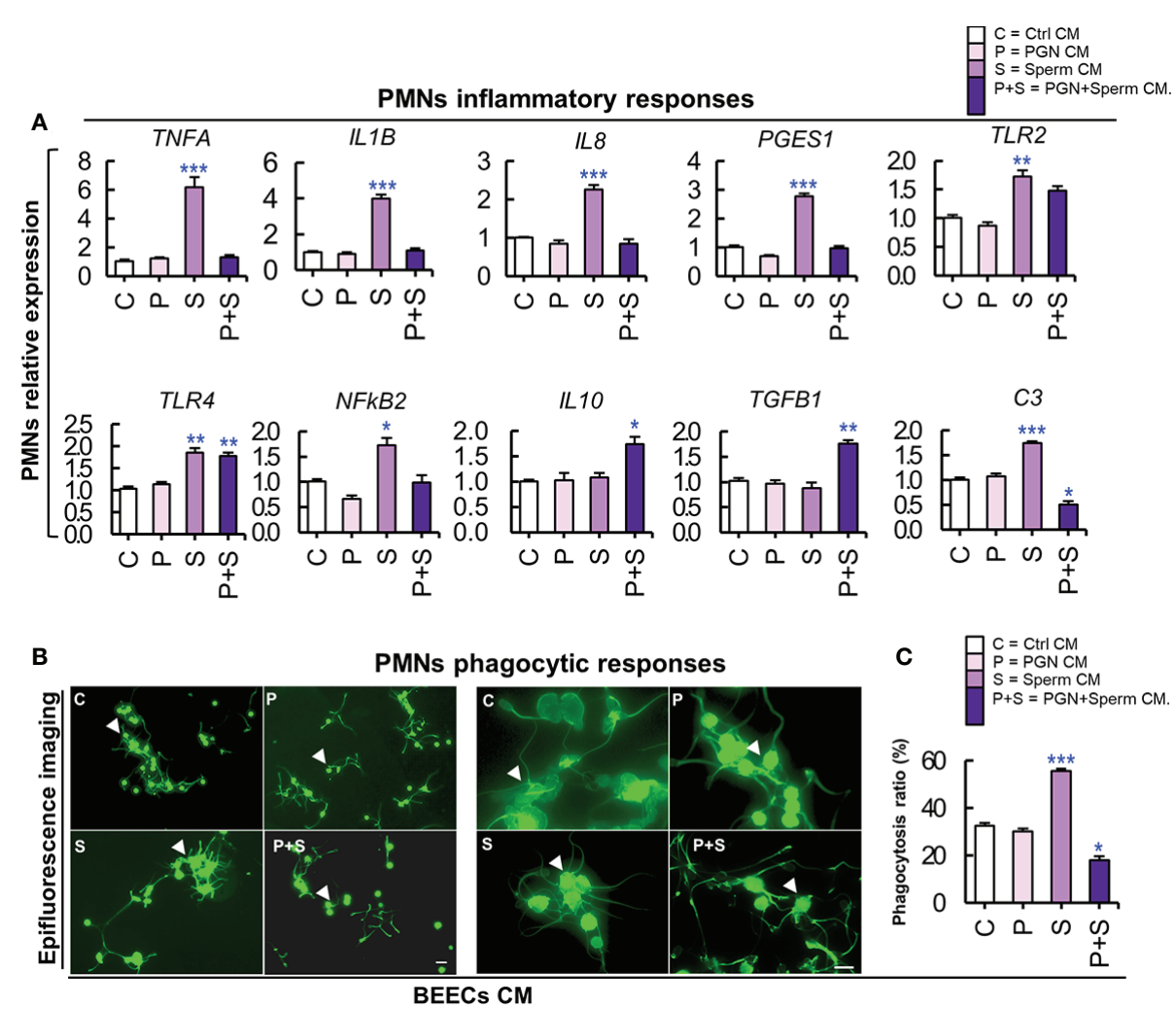

FIGURE 6 | (A) PGN suppressed the stimulatory impact of sperm-BEECs conditioned media on the transcription of major pro-and anti-inflammatory genes of PMNs in vitro. Mature PMNs $\left(7 \times 10^{6}\right.$ cells $\left.\mathrm{ml}^{-1}\right)$ isolated from circulating blood of healthy cows were challenged for $2 \mathrm{~h}$ in CM obtained from BEECs, exposed to PGN (10 $\mathrm{pg} \mathrm{ml}^{-1}$ ) for $24 \mathrm{~h}$, washed, and co-cultured with sperm for $6 \mathrm{~h}$. The mRNA expression of different genes was quantified using RT-PCR assay. Data are presented as mean \pm SEM of 3 independent experiments where asterisks denote a significant variance $\left({ }^{*} P<0.05\right.$ or $\left.{ }^{* *} P<0.01\right)$ between the different groups when compared to the control group. (B) PGN downregulated the stimulatory impact of sperm-BEEC conditioned medium on phagocytic activity of PMNs. Similarly, mature PMNs $\left(7 \times 10^{6}\right.$

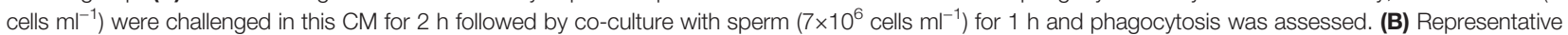
images of PMN phagocytosis for sperm. Magnification: 200× (left? panel) and 400× (right panel). (Control; C, PGN; P, sperm; S, and PGN + sperm; P+S). Arrow heads indicate PMNs phagocytosing sperm. Scale bar $=20 \mu \mathrm{m}$. (C) The phagocytosis ratio was independently assessed by two observers for 1000 cells using an all in one epifluorescence high-resolution imaging system (Keyence, BZ-X800, Osaka, Japan). Results are representative of 3 independent trials using 3 different healthy animals. Data are presented as mean \pm SEM with asterisk denoting a significant variance $\left({ }^{*} P<0.05\right)$ between the different groups when compared to the control group. Asterisk denotes a significant variance $\left({ }^{\star} P<0.05\right)$ between the 'Sperm' and 'PGN+Sperm' groups.

increased sperm attachment to endometrial glands and surface epithelium via the upregulation of a CD44 adhesion molecule. The results demonstrated that during mild pathophysiological conditions, the presence of PGN residues disrupts the transient physiological inflammation induced by sperm in the endometrium epithelium, possibly leading to impairment of uterine clearance and subsequent embryo receptivity and development.

Initiation of innate immune responses through TLRs signaling pathway depends on the nature of the stimulus, stimulation time, and the interaction surfaces on their extracellular domain which activates multiple signaling adaptor proteins through at least two distinct pathways, MyD88-dependent pathway (utilized by all TLRs) and TRIF-dependent pathway (utilized by TLR3 and TLR4 only) $(11,32,33)$. Previously, we reported that sperm induced proinflammatory responses in BEECs via TLR2/4 signaling pathway (17). In the present study, the stimulation of BEECs with high concentrations of TLR4 agonists, LPS, either independently or combined with sperm, induced drastic inflammatory responses in BEECs compared to sperm. Additionally, the pre-exposure of BEECs to low levels of LPS induced slight inflammatory responses in BEECs, but did not interfere with the subsequent sperm-induced inflammation in BEECs. LPS is a highly potent endotoxin (9) which directly binds to the extracellular domain of TLR4, and rapidly stimulates a wide range of downstream signaling cascades (within a few minutes), leading to initiation of a timedependently progressing inflammatory responses in endometrial cells $(17,34)$. While, sperm cells trigger weak and transient inflammatory responses in endometrial cells and their interaction with TLR4 domain might be mediated by endogenous ligands (17). Therefore, we suggests that the TLR4-mediated endometrial recognition of sperm or LPS might be generated via different intracellular signaling cascades and downstream adaptor proteins. 
Ex vivo organ explants of endometrium
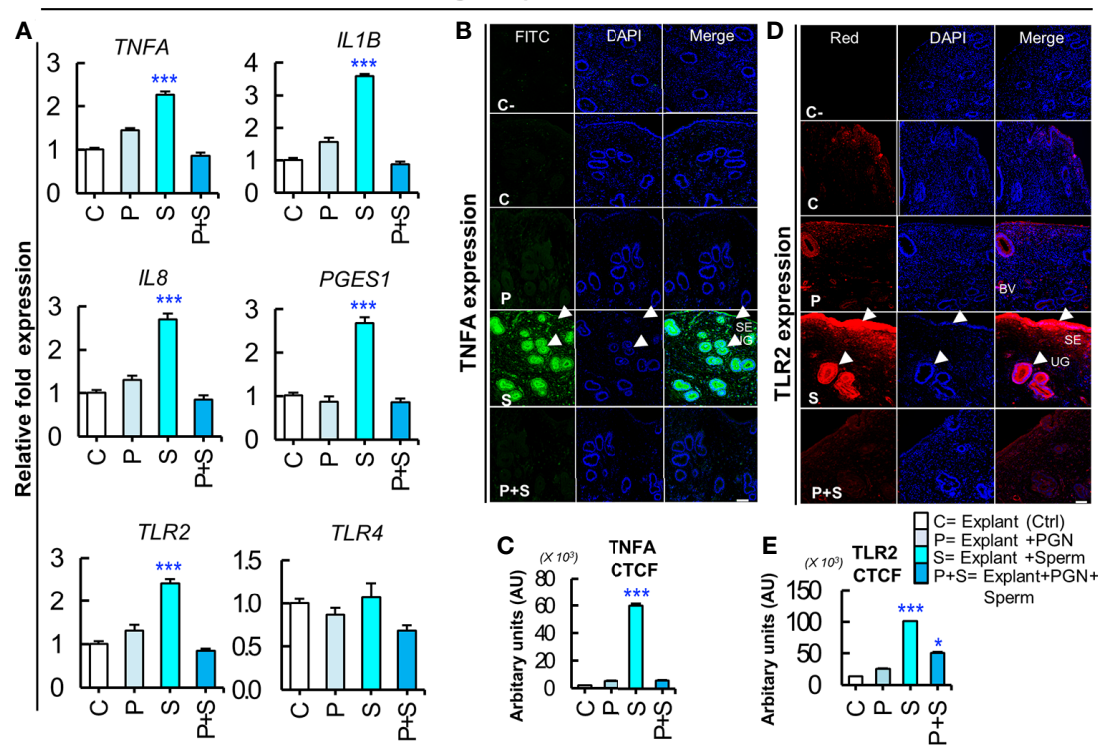

F

Ex vivo organ explants of endometrium

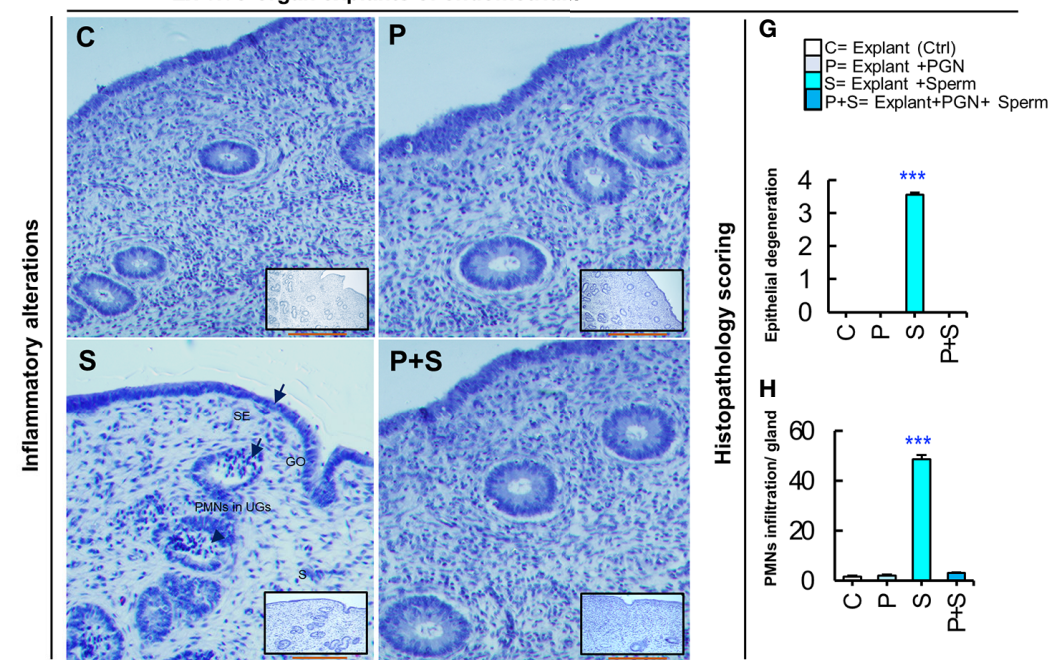

FIGURE 7 | PGN suppresses the sperm-triggered alterations in inflammatory genes and protein expression as well as histomorphology in ex vivo explants of endometrium. (A) Real-time PCR assay of the mRNA transcription levels of sperm-stimulated inflammatory genes after exposure to PGN. Fresh pre-ovulatory explants were exposed to PGN $\left(10 \mathrm{pg} \mathrm{ml}^{-1}\right)$ for $3 \mathrm{~h}$ followed by co-culturing with sperm for $3 \mathrm{~h}$. The mRNA expression of different inflammatory genes was assessed. Asterisk denote a significant variance $\left.{ }^{* * *} P<0.001\right)$ between the different groups when compared to the control group and data are presented as mean \pm SEM. (B) Immunofluorescence assay of candidate inflammatory marker (TNFA) in ex vivo organ explants of endometrium. Immunostaining confirmed intense accumulation of TNFA (green) in UGs and surface epithelium (SE) (arrow heads) compared to stroma (S) in the "S" group and this was abrogated in the "P+S" group. (C) Semiquantitative scoring of corrected total cell fluorescence (CTCF) of TNFA was based on mean fluorescence intensity (MFI) and integrated density (IntDen) by ImageJ software expressed as arbitrary fluorescence units (AU). DAPI was set as the nuclear counterstain (blue). Normal rabbit lgG replaced the primary antibody in the negative control (C-). (D) Immunofluorescence assay of the signaling marker (TLR2) in ex vivo organ explants of endometrium. Immunostaining confirmed intense accumulation of TLR2 (red) induced by sperm ("S" group) specifically in UGs and SE (arrow heads), compared to stroma (S) and compared to the C and other treated groups $(\mathrm{P}$, and $\mathrm{P}+\mathrm{S})$. (E) Semiquantitative scoring of corrected total cell fluorescence (CTCF) of TLR2 expressed as arbitrary fluorescence units (AU). Fluorescence signal was captured using an all-in-one epifluorescence high-resolution imaging system (Keyence, BZ-X800, Osaka, Japan). BZ-X GFP (OP-87763), BZ-X RED (OP-87765), and BZ-X DAPI (OP-87762) filters were set for green, red and blue wavelengths, respectively. Random images from 3 independent experiments (using 3 different healthy pre-ovulatory uteri from 3 different animals) were evaluated and readings were statistically analyzed where asterisks denote a significant variance $\left({ }^{*} P<0.05\right.$, and $\left.{ }^{* * *} P<0.001\right)$ between the different groups when compared to the control group and data are presented as mean \pm SEM. Magnification: 200x. Scale bar $=50 \mu \mathrm{m}$. (F) Representative photomicrographs showing delicate inflammatory reaction triggered by sperm in "S" group represented by reversible endometrial tissue injury particularly in uterine glands (UGs), surface epithelium (SE) or gland opening (GO) (short arrows), but not in stroma (S). Hematoxylin and Eosin (H\&E) semiquantitative scoring of (G) epithelial degeneration, and $\mathbf{( H )}$ mild neutrophilic infiltration (PMNs) (arrow heads) in UGs was used to quantify degree of histopathological alterations compared to other groups $(\mathrm{C}, \mathrm{P}$ and $\mathrm{P}+\mathrm{S})$ where asterisks denote a significant variance $\left.{ }^{* * *} \mathrm{P}<0.001\right) \pm \mathrm{SEM}$. Magnification: $400 \times$. Scale bar $=200 \mu \mathrm{m}$. 
Ex vivo organ explants of endometrium
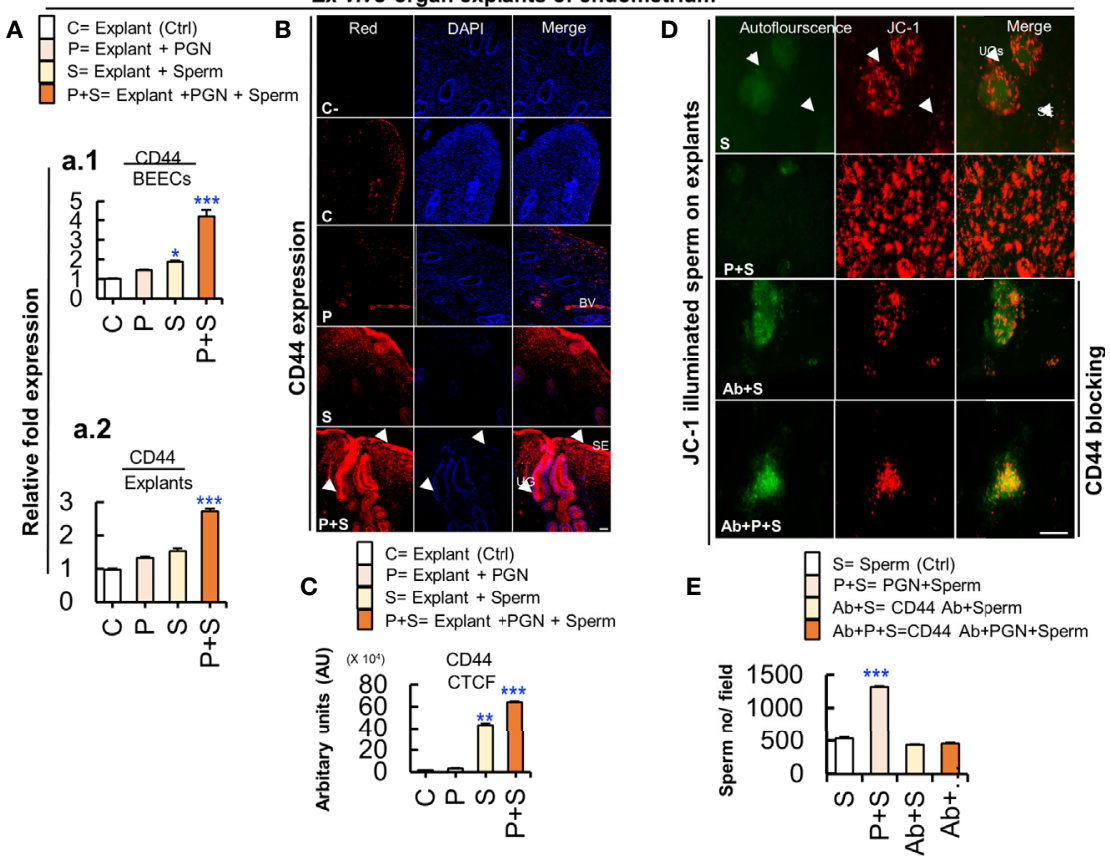

FIGURE 8 | Cluster of differentiation 44 (CD44) is expressed in the bovine endometrium and is implicated in the massive PGN-triggered sperm attachment to endometrial glands and luminal epithelium. (A) RT-PCR assay revealed upregulated CD44 mRNA expression in BEECs in vitro (a.1) and in endometrial tissue ex vivo (a.2). Data are presented as mean \pm SEM of 3 independent experiments using epithelial cells or explants from 3 different uteri (3 wells/treatment/experiment). Asterisks denote a significant variance $\left({ }^{\star} P<0.05\right.$, or $\left.{ }^{* * *} P<0.001\right)$. (B) Immunofluorescence assay of cellular adhesion molecule (CD44) in ex vivo organ explants of endometrium. Immunostaining confirmed intense accumulation of CD44 (red) (arrow heads) induced by PGN+Sperm ("P+S" group) specifically in UGs and in SE (arrow heads) compared to sperm "S" and other groups (C and P). Magnification: $200 \times$. Scale bar $=50 \mu \mathrm{m}$. (C) Semiquantitative scoring of corrected total cell fluorescence (CTCF) of CD44 expressed in UGs as arbitrary fluorescence units (AU). Data are presented as mean \pm SEM of 3 independent experiments using explants from 3 different uteri (3 wells/treatment/experiment). Asterisks denote a significant variance $\left({ }^{* *} P<0.01\right.$ or $\left.{ }^{* * *} P<0.001\right)$. (D) PGN triggered massive sperm association to uterine glands (UGs) (arrows) and surface epithelium (SE) (arrow heads) compared to control (sperm). Pre-exposure of endometrial explants to antirabbit CD44 polyclonal antibody for $3 \mathrm{~h}$ followed by exposure to $\mathrm{PGN}\left(10 \mathrm{pg} \mathrm{ml}{ }^{-1}\right.$ ) for $3 \mathrm{~h}$, and co-culturing with sperm for $3 \mathrm{~h}$ (Ab+P+S) resulted in minimizing $\mathrm{PGN}$ triggered sperm attachment $(\mathrm{P}+\mathrm{S})$ in endometrial explants and most of spermatozoa were released actively and found freely swimming on the surface epithelium (Ab + PGN+S) (Supplementary Video 4). Magnification: 200x. Scale bar $=200 \mu \mathrm{m}$. (E) ImageJ software (version 1.51j8) was used for counting localized spermatozoa in (Supplementary Videos 1 and 2). Data are presented as mean \pm SEM of 3 independent experiments using explants from 3 different uteri. Asterisks denote a significant variance $\left.{ }^{* * *} P<0.001\right)$ between the different groups compared to control (sperm only).

Further investigations are needed to identify different and/or interactive downstream adaptor molecules of TLR4 signaling pathway triggered by sperm or LPS in the endometrial epithelium.

Interestingly, our data showed that low concentrations of TLR2 agonist, PGN, failed to trigger any significant inflammatory responses in BEECs, but they completely blocked sperm-induced inflammation in BEECs, suggesting that there is a pivotal connection between endometrial responses to PGN and sperm, possibly through the TLR2 pathway. However, the ability of high concentrations of PGN to independently induce inflammatory responses in BEECs might mask their suppressive effect on sperm-triggered immune responses in BEECs when combined with sperm. Likewise, the addition of PGN (10 pg ml${ }^{-1}$ ) into BEECs culture, primed by luteal stage levels of E2 and P4, followed by co-culturing with sperm, clearly suppressed sperminduced inflammatory responses in BEECs (Supplementary Figure 2), meaning that the suppressive effect of PGN on the sperminduced inflammation in BEECs was not related to the levels of sex steroids. Moreover, our findings that either pre-exposure or co- exposure of BEECs to PGN (10 pg ml$l^{-1}$ ) blocked the BEECs inflammatory responses to sperm (Supplementary Figure 3) indicate that PGN may competitively occupy and block spermTLR2 binding and thereby interferes with sperm-triggered immune responses in BEECs (35). This could be attributed to the high affinity of PGN to bind to TLR2 receptors (36). Moreover, the results showed that, in a dose-dependent manner, PGN stimulated the transcription of inflammatory cytokines after $1 \mathrm{~h}$, reached its peak at $3 \mathrm{~h}$, started to subside after $6 \mathrm{~h}$, and completely subsided after 12 to $24 \mathrm{~h}$. Interestingly, the pattern of endometrial inflammation induced by PGN was relatively similar to that induced by the synthetic TLR2 agonist, pam3Cys (17), as well as sperm (16), suggesting again that the TLR2 pathway is involved in the PGN and sperm sensing system in BEECs. Additionally, PGN persistently upregulated transcription levels of IL10 and TGFB1 until $12 \mathrm{~h}$ and subsided at $24 \mathrm{~h}$. These results clearly show that PGN triggers rapid and transient inflammatory responses in BEECs, which disappear as the amplitude of the inflammation resolves, and reaches baseline after $24 \mathrm{~h}$. By this process, BEECs might 
undergo a state of inactivation due to relative exhaustion of their inflammatory depot (37), thereby losing their ability to sense and respond to sperm signals through TLR2 (an autocrine effect). Although sperm express TLR2 receptors (38), our data showed that pre-exposure of sperm to PGN did not interfere with the subsequent sperm-induced inflammation in BEECs in vitro (Supplementary Figure 4), demonstrating that sperm TLR2 are not involved in the suppressive effect of PGN on sperm immune responses in endometrial epithelium.

Immunoblotting analysis revealed that either PGN or sperm stimulated the phosphorylation levels of p38MAPK, ERK1/2, and JNK as downstream targets of MyD88-dependent signaling pathways in BEECs while they did not stimulate the phosphorylation of the IRF3 as downstream targets of TRIF-dependent signaling pathways. This suggests that TLR2 signaling, in particular MyD88dependent pathway, acts as a commonly-shared pathway for PGN and sperm recognition in BEECs. The results showed that PGN combination with sperm prevented sperm-induced phosphorylation of JNK in BEECs. JNK is a stress-related adaptor protein $(39,40)$ essential for activation of transcription factor (AP-1) and, consequently, amplification of the inflammatory signal (41). This delicate modulation of TLR2 signaling, induced by PGN, could disturb the entire spermtriggered TLR2 signal transduction cascade and drive a newlydifferentiated inert pathway that impairs the production of inflammatory cytokines/chemokines and dampens BEEC reactivity to sperm $(42,43)$. Nevertheless, activation or blockage of the TLR2 pathway using its synthetic agonist or antagonist prevented the sperm-induced inflammatory response and PGN effect respectively, which further confirms that BEECs recognize sperm signals mainly via the TLR2 pathway. Given that MyD88dependent pathway is a common pathway for TLR2 and TLR4 (11) together with the fact that TLR2 agonist and antagonist can induce a partial cross-tolerance with TLR4 pathway $(44,45)$, it seems technically very difficult to clarify the potential contribution of the whole TLR2/4 signaling complex in sperm recognition by endometrial epithelium which deserves further investigations.

Insemination triggers transient physiological inflammatory responses in the endometrium characterized by recruitment of PMNs into the uterine lumen within 2 to $12 \mathrm{~h}$ after insemination $(14,46)$ as the first essential innate immune responses for clearance of bacteria, excess/dead sperm, and tissue debris and these responses enhance endometrial receptivity and pre-implantation embryo development (14). Therefore, sustained or excessive and persistent levels of locally-infiltrated PMNs, as observed during pathophysiological conditions including subclinical endometritis (SE) (47), could interrupt uterine clearance and subsequent embryo receptivity. Our results showed that sperm-BEECs CM induced pro-inflammatory responses in PMNs as a paracrine effect of the sperm-endometrial secretome, while pre-exposure to PGN blocked these responses and increased mRNA expressions of antiinflammatory genes (IL10 and TGFB1). Accordingly, PMNs incubation in sperm-BEECs CM increased PMNs phagocytic activity for sperm while pre-exposure to PGN reduced it. The inhibitory action of pre-exposure to PGN on PMN phagocytosis for sperm might be related to the upregulation of mRNA expression of
IL10 and TGFB1, PMN's phagocytosis-suppressive factors (48), and to the suppression of mRNA expression of C3, PMN's phagocytosis-stimulatory factor (49), in PMNs. Moreover, PGN blocked sperm-induced upregulations of mRNA expressions of IL8 in PMNs, a strong chemoattractant for PMNs (47). Overall, these results, in part, could explain the molecular mechanism by which the presence of traces of PGN during uterine infection exerts deleterious effects on sperm-endometrial interactions through blocking the physiological endometrial inflammation induced by sperm, thereby preventing the transient PMNs influx and phagocytosis for sperm, which may account for reduced fertility during mild infections. Indeed, it has been shown that the absence of PMNs infiltration into the uterine lumen $4 \mathrm{~h}$ after insemination was associated with a reduced conception rate in SE cows (50).

In the same context, using an ex vivo intact bovine endometrium explants, we found that PGN clearly blocked sperm-induced inflammatory responses in the endometrial tissue. Additionally, sperm induced a mild degree of reversible tissue injury (epithelial degeneration) in the glandular and surface epithelium with PMNs infiltrations mainly into uterine glands, indicating that the sperminduced inflammation was not detrimental to the endometrial tissue (51). However, addition of PGN completely blocked sperm-induced alterations in the architecture of endometrial tissues. These observations substantiated our main finding that TLR2 is the central sperm recognition system in endometrial epithelium, specifically in glands. Consequently, disruption of the TLR2 system by PGN could be associated with a nonfunctional mucosal sensing system for sperm, thereby blocking transient inflammatory responses of sperm in the bovine endometrium.

It has been shown that active sperm do not bind to the surface epithelium of the endometrial mucosa, but they enter and are found in the glands (18). Unexpectedly, we found that PGN massively increased attachment of sperm to endometrial glands, and relatively so, to the surface epithelium. In contrast, the pretreatment of endometrial tissues with LPS did not alter sperm attachment to endometrial epithelium. Given that, PGN can induce CD44 expression through the TLR2 pathway (52) which possesses potent adhesion properties (53) and is expressed in the sperm reservoir to support sperm attachment to the oviductal epithelium $(54,55)$. Therefore, we hypothesized that CD44 might have a pivotal role in this PGN-triggered sperm attachment to the endometrial epithelium. Our results showed that PGN together with sperm upregulated CD44 expression in uterine glands and surface epithelia. Interestingly, addition of an anti-CD44 neutralizing antibody into a PGN-sperm-explant coculture decreased sperm attachment into glands and surface epithelia but did not remove the suppressive effect of PGN on the sperm-induced inflammation (Supplementary Figure 5). Similarly, it has been shown that during fertilization, cumulus cells of ovulated cumulus-oocyte complexes express CD44 to recognize hyaluronan fragments generated from sperm and thereby inflammatory responses in cumulus cells are induced in a TLR2/4-dependent pathway, while addition of a neutralizing antibody for CD44 did not interfere with sperm-triggered inflammation in cumulus cells (56). Previously we reported that, in a dose-dependent manner, sperm induces pro- 
inflammatory responses in BEECs in vitro (16). Therefore, we suggest that PGN blocks the TLR2-mediated sperm sensing system regardless of its ability to increase sperm attachment to the endometrial epithelium via the upregulation of CD44 expression in the endometrial tissue. The ability of PGN to trigger sperm attachment with the endometrial epithelium together with its ability to block sperm-induced PGES1 mRNA expression, which is involved in uterine contractility (57), may impair sperm transport and uterine clearance.

Together, our findings may serve as a proof of concept for mechanisms underlying competitive pathophysiological interactions during either insemination of a mildly infected uterus "pre-exposure" or infection during insemination "co-exposure". Traces of PGN derived from virtually all bacteria disrupt the sperm sensing system and the subsequently induced inflammatory responses in the bovine endometrium, which in turn might interfere with fertility. The proposed mechanisms involve a desensitized mucosal innate immune system via modulation of the MyD88-dependent pathway of TLR2 signaling, inactivation of locally-infiltrating sperm-immune scavengers, PMNs, and triggering sperm attachment to the endometrial tissue, thereby impairing uterine clearance and embryo receptivity. However, apart from our in vitro and ex vivo investigations, an important next step will be further in vivo investigations to understand in vivo uterine pathophysiology and its deleterious impact on fertility through, for example, a reduced conception rate.

\section{DATA AVAILABILITY STATEMENT}

The data sets presented in this study can be found in online repositories. The names of the repository/repositories and accession number(s) can be found in the article/Supplementary Material.

\section{ETHICS STATEMENT}

The animal study was reviewed and approved by The Committee of Animal Experiments at Obihiro University of Agriculture and Veterinary Medicine (Permit no. 27-74).

\section{AUTHOR CONTRIBUTIONS}

IFE conceived of the study. WG, AAR, MaS, and AM initiated the study design, and MAM, MAZ, IA, TK, MoS, and FN helped with implementation. IFE and MAM provided statistical analysis. All authors contributed to the article and approved the submitted version.

\section{REFERENCES}

1. Schjenken JE, Moldenhauer LM, Zhang B, Care AS, Groome HM, Chan HY, et al. MicroRNA miR-155 is required for expansion of regulatory $\mathrm{T}$ cells to mediate robust pregnancy tolerance in mice. Mucosal Immunol (2020) 13 (4):609-25. doi: 10.1038/s41385-020-0255-0

2. Janeway CA Jr, Medzhitov R. Innate immune recognition. Annu Rev Immunol (2002) 20:197-216. doi: 10.1146/annurev.immunol.20.083001.084359

\section{FUNDING}

This work was supported by Grant-in-Aid for Scientific Research (16H05013, 17F17407, and 20H03122) from Japan Society for the Promotion of Science (JSPS), Japan Association for Livestock New Technology, and Livestock Promotional Funds of Japan Racing Association (JRA). IE has received a scholarship for his PhD program from the Ministry of Higher Education, Egypt.

\section{ACKNOWLEDGMENTS}

The authors would like to thank Prof. Murray Clayton, University of Wisconsin-Madison, USA, for his intensive English correction, and Genetics Hokkaido for their generous supply of the semen straws used in all the experiments.

\section{SUPPLEMENTARY MATERIAL}

The Supplementary Material for this article can be found online at: https://www.frontiersin.org/articles/10.3389/fimmu.2020. 619408/full\#supplementary-material

Supplementary Video 1 | JC-1 mitochondrial staining illuminates midpieces of sperm associated with the surface of the endometrial glands. After addition of sperm to preovulatory ex vivo organ explants of endometrium, sperm aggregated at the glandular opening after $5 \mathrm{~min}$ (and again after $30 \mathrm{~min}$ ) and (Figure 7A). The fluorescence videos were captured using a BZ-X RED (OP-87765) filter and then ImageJ software (version 1.51j8) was used for counting of localized spermatozoa Counts of nine fields, of equal frame size.

Supplementary Video 2 | PGN (natural TLR2 ligand) triggered massive sperm association to glands and luminal epithelium in endometrial explants ex vivo. Large clusters of motile viable sperm with beating tails accumulated at uterine glands (UDs) and between glands (in the surface epithelium) (SE). The video was captured $5 \mathrm{~min}$ (and again after $30 \mathrm{~min}$ ) after addition of sperm that followed a $3 \mathrm{~h}$ preexposure to PGN $\left(10 \mathrm{pg} \mathrm{m}^{-1}\right)$.

Supplementary Video 3 I pam3Cys (synthetic TLR2 ligand) triggered massive sperm association to glands and luminal epithelium in endometrial explants ex vivo. Large clusters of motile viable sperm with beating tails accumulated at uterine glands (UDs) and between glands (in the surface epithelium) (SE). The video was captured $5 \mathrm{~min}$ (and again after $30 \mathrm{~min}$ ) after addition of sperm that followed a $3 \mathrm{~h}$ pre-exposure to pam3Cys (10 $\mathrm{pg} \mathrm{ml}^{-1}$ ).

Supplementary Video 4 | CD44 blocking prevented PGN-triggered sperm association in uterine glands (UDs) and surface epithelium (SE) in endometrial explants ex vivo. The video was captured $5 \mathrm{~min}$ (and again after $30 \mathrm{~min}$ ) after addition of sperm that followed a $3 \mathrm{~h}$ pre-treatment with CD44 Ab and a $3 \mathrm{~h}$ pre-exposure to PGN (10 pg $\mathrm{ml}^{-1}$ ). Most of the spermatozoa that were released form UGs and SE were found freely swimming on the SE showing normal motility and viability. 
receptors TLR2, TLR1, and TLR6. Endocrinology (2014) 4:1453-65. doi: 10.1210/en.2013-1822

6. Schaefer TM, Desouza K, Fahey JV, Beagley KW, Wira CR. Toll-like receptor (TLR) expression and TLR-mediated cytokine/chemokine production by human uterine epithelial cells. Immunology (2004) 112(3):428-36. doi: 10.1111/j.1365-2567.2004.01898.x

7. Gabler C, Fischer C, Drillich M, Einspanier R, Heuwieser W. Time-dependent mRNA expression of selected pro-inflammatory factors in the endometrium of primiparous cows postpartum. Reprod Biol Endocrinol (2010) 8:152. doi: 10.1186/1477-7827-8-152

8. Chapwanya A, Meade KG, Foley C, Narciandi F, Evans AC, Doherty ML, et al. The postpartum endometrial inflammatory response: a normal physiological event with potential implications for bovine fertility. Reprod Fert Dev (2012) 24:1028-39. doi: 10.1071/RD11153.8

9. De Tejada GM, Heinbockel L, Ferrer-Espada R, Heine H, Alexander C, Bárcena-Varela S, et al. Lipoproteins/peptides are sepsis-inducing toxins from bacteria that can be neutralized by synthetic anti-endotoxin peptides. Sci Rep (2015) 5:14292. doi: 10.1038/srep14292

10. Dohmen MJ, Joop K, Sturk A, Bols PE, Lohuis JA. Relationship between intrauterine bacterial contamination, endotoxin levels and the development of endometritis in postpartum cows with dystocia or retained placenta. Theriogenology (2000) 54(7):1019-32. doi: 10.1016/s0093-691x(00)00410-6

11. Akira S, Takeda K, Kaisho T. Toll-like receptors: critical proteins linking innate and acquired immunity. Nat Immunol (2001) 2(8):675-80. doi: $10.1038 / 90609$

12. Chi H, Barry SP, Roth RJ, Wu JJ, Jones EA, Bennett AM, et al. Dynamic regulation of pro-and anti-inflammatory cytokines by MAPK phosphatase 1 (MKP-1) in innate immune responses. Proc Natl Acad Sci U S A (2006) 103 (7):2274-9. doi: 10.1073/pnas.0510965103

13. Kashiwagi I, Morita R, Schichita T, Komai K, Saeki K, Matsumoto M, et al. Smad 2 and Smad 3 inversely regulate TGF- $\beta$ autoinduction in Clostridium butyricum-activated dendritic cells. Immunity (2015) 43:65-79. doi: 10.1016/ j.immuni.2015.06.010

14. Katila T. Post-mating inflammatory responses of the uterus. Reprod Domest Anim (2012) 47 Suppl 5:31-41. doi: 10.1111/j.1439-0531.2012.02120.x

15. Marey MA, Yousef MS, Liu J, Morita K, Sasaki M, Hayakawa H, et al. Angiotensin II increases sperm phagocytosis by neutrophils in vitro: A possible physiological role in the bovine oviduct. Mol Reprod Dev (2016) 83 (7):630-9. doi: 10.1002/mrd.22672

16. Elweza A, Ezz MA, Acosta TJ, Talukder AK, Shimizu T, Hayakawa H, et al. A proinflammatory response of bovine endometrial epithelial cells to active sperm in vitro. Mol Reprod Dev (2018) 85(3):215-26. doi: 10.1002/mrd.22955

17. Ezz MA, Marey MA, Elweza AE, Kawai T, Heppelmann M, Pfarrer C, et al. TLR2/4 signaling pathway mediates sperm-induced inflammation in bovine endometrial epithelial cells in vitro. PloS One (2019) 14(4):e0214516. doi: 10.1371/journal.pone.0214516

18. Akthar I, Suarez S, Morillo VA, Sasaki M, Ezz MA, Takahashi KI, et al. Sperm enter glands of preovulatory bovine endometrial explants and initiate inflammation. Reproduction (2020) 159:181-92. doi: 10.1530/REP-19-0414

19. Borges ÁM, Healey GD, Sheldon IM. Explants of intact endometrium to model bovine innate immunity and inflammation ex vivo. Am J Reprod Immunol (2012) 67(6):526-39. doi: 10.1111/j.1600-0897.2012.01106.x

20. Grabowski M, Bermudez M, Rudolf T, Šribar D, Varga P, Murgueitio MS, et al. Identification and validation of a novel dual small-molecule TLR2/8 antagonist. Biochem Pharmacol (2020) 177:113957. doi: 10.1016/j.bcp. 2020.113957

21. Yousef MS, Marey MA, Hambruch N, Hayakawa H, Shimizu T, Hussien HA, et al. Sperm binding to oviduct epithelial cells enhances TGFB1 and IL10 expressions in epithelial cells as well as neutrophils in vitro: prostaglandin E2 as a main regulator of anti-inflammatory response in the bovine oviduct. PloS One (2016) 11(9):e0162309. doi: 10.1371/journal.pone.0162309

22. Schefe JH, Lehmann KE, Buschmann IR, Unger T, Funke-Kaiser H. Quantitative real-time RT-PCR data analysis: current concepts and the novel "gene expression's C T difference" formula. Int J Mol Med (2006) 84 (11):901-10. doi: 10.1007/s00109-006-0097-6

23. Marey MA, Matsukawa H, Sasaki M, Ezz MA, Yousef MS, Takahashi KI, et al. Bovine oviduct epithelial cells suppress the phagocytic activity of neutrophils towards sperm but not for bacteria in vitro: Immunofluorescence and electron microscopic observations. Histol Histopathol (2020) 35(6):589-97. doi: $10.14670 / \mathrm{HH}-18-172$

24. Gibson-Corley KN, Olivier AK, Meyerholz DK. Principles for valid histopathologic scoring in research. Vet Pathol (2013) 50(6):1007-15. doi: $10.1177 / 0300985813485099$

25. Zhang S, Mao W, Li Q, Gao R, Zhang Y, Gao L, et al. Concentration effect of prostaglandin E2 on the growth factor expression and cell proliferation in bovine endometrial explants and their kinetic characteristics. Reprod Domest Anim (2018) 53(1):143-51. doi: 10.1111/rda.13083

26. Suvarna KS, Layton C, Bancroft JD. Bancroft's Theory and Practice of Histological Techniques. 8th Edition. London: Elsevier (2019). p. 139-52. doi.org/10.1016/C2015-0-00143-5.

27. Merriam AA, Xu X, Davisson RL, Sones JL, Douglas NC. 901: Alterations in the complement pathway in a mouse model of preeclampsia. Am J Obstet Gynecol (2017) 1:S514-5. doi: 10.1096/fj.201701008R

28. Ran X, Zhou P, Zhang K. Autophagy plays an important role in stemness mediation and the novel dual function of EIG121 in both autophagy and stemness regulation of endometrial carcinoma JEC cells. Int J Oncol (2017) 51 (2):644-56. doi: 10.3892/ijo.2017.4047

29. Benner M, Ferwerda G, Joosten I, van der Molen RG. How uterine microbiota might be responsible for a receptive, fertile endometrium. Hum Reprod Update (2018) 24(4):393-415. doi: 10.1093/humupd/dmy012

30. Franasiak JM, Werner MD, Juneau CR, Tao X, Landis J, Zhan Y, et al. Endometrial microbiome at the time of embryo transfer: next generation sequencing of the $16 \mathrm{~S}$ ribosomal subunit. J Assist Reprod Genet (2016) 33 (1):129-36. doi: 10.1007/s10815-015-0614-z

31. Chen C, Song X, Wei W, Zhong H, Dai J, Lan Z, et al. The microbiota continuum along the female reproductive tract and its relation to uterine-related diseases. Nat Commun (2017) 8(1):875. doi: 10.1038/s41467-017-00901-0

32. Ronni T, Agarwal V, Haykinson M, Haberland ME, Cheng G, Smale ST. Common interaction surfaces of the toll-like receptor 4 cytoplasmic domain stimulate multiple nuclear targets. Mol Cell Biol (2003) 23(7):2543-55. doi: $10.1128 / \mathrm{mcb} .23 .7 .2543-2555.2003$

33. El-Zayat SR, Sibaii H, Mannaa FA. Toll-like receptors activation, signaling, and targeting: an overview. Bull Natl Res Cent (2019) 43:187. doi: 10.1186/ s42269-019-0227-2

34. Cronin JG, Turner ML, Goetze L, Bryant CE, Sheldon IM. Toll-like receptor 4 and MYD88-dependent signaling mechanisms of the innate immune system are essential for the response to lipopolysaccharide by epithelial and stromal cells of the bovine endometrium. Biol Reprod (2012) 86(2):51. doi: 10.1095/ biolreprod.111.092718

35. Wang JE, Dahle MK, McDonald M, Foster SJ, Aasen AO, Thiemermann C, et al. Peptidoglycan and lipoteichoic acid in gram-positive bacterial sepsis: receptors, signal transduction, biological effects, and synergism. Shock (2003) 20(5):402-14. doi: 10.1097/01.shk.0000092268.01859.0d

36. waki D, Mitsuzawa H, Murakami S, Sano H, Konishi M, Akino T, et al. The extracellular toll-like receptor 2 domain directly binds peptidoglycan derived from Staphylococcus aureus. J Biol Chem (2002) 27:24315-20. doi: 10.1074/ jbc.M107057200

37. Wang J, Ford HR, Grishin AV. NF- אB-mediated expression of MAPK phosphatase- 1 is an early step in desensitization to TLR ligands in enterocytes. Mucosal Immunol (2010) 5:523-34. doi: 10.1038/mi.2010.35

38. Fujita Y, Mihara T, Okazaki T, Shitanaka M, Kushino R, Ikeda C, et al. Tolllike receptors (TLR) 2 and 4 on human sperm recognize bacterial endotoxins and mediate apoptosis. Hum Reprod (2011) 26(10):2799-806. doi: 10.1093/ humrep/der234

39. Fang L, Wu HM, Ding PS, Liu RY. TLR2 mediates phagocytosis and autophagy through JNK signaling pathway in Staphylococcus aureus-stimulated RAW264. 7 cells. Cell Signal (2014) 26:806-14. doi: 10.1016/j.cellsig.2013.12.016

40. Johnnidis JB, Harris MH, Wheeler RT, Stehling-Sun S, Lam MH, Kirak O, et al. Regulation of progenitor cell proliferation and granulocyte function by microRNA-223. Nature (2008) 451(7182):1125-9. doi: 10.1038/nature06607

41. Ventura JJ, Kennedy NJ, Lamb JA, Flavell RA, Davis RJ. c-Jun NH2-terminal kinase is essential for the regulation of AP-1 by tumor necrosis factor. Mol Cell Biol (2003) 23(8):2871-82. doi: 10.1128/mcb.23.8.2871-2882.2003

42. Laman JD, Bert A, Power C, Dziarski R. Bacterial peptidoglycan as a driver of chronic brain inflammation. Trends Mol Med (2020) 26(7):670-82. doi: 10.1016/j.molmed.2019.11.006 
43. Troha K, Nagy P, Pivovar A, Lazzaro BP, Hartley PS, Buchon N. Nephrocytes Remove Microbiota-Derived Peptidoglycan from Systemic Circulation to Maintain Immune Homeostasis. Immunity (2019) 51(4):625-37. doi: 10.1016/j.immuni.2019.08.020

44. Geisel J, Kahl F, Müller M, Wagner H, Kirschning CJ, Autenrieth IB, et al. IL-6 and maturation govern TLR2 and TLR4 induced TLR agonist tolerance and cross-tolerance in dendritic cells. J Immunol (2007) 179(9):5811-8. doi: 10.4049/jimmunol.179.9.5811

45. Cheng K, Wang X, Zhang S, Yin H. Discovery of small-molecule inhibitors of the TLR1/TLR2 complex. Angew Chem Int Ed Engl (2012) 51(49):12246-9. doi: 10.1002/anie.201204910

46. LeBlanc MM. Advances in the Diagnosis and Treatment of Chronic Infectious and Post-Mating-Induced Endometritis in the Mare. Reprod Domest Anim (2010) 45(Suppl 2):21-7. doi: 10.1111/j.1439-0531.2010.01634.x

47. Cronin JG, Kanamarlapudi V, Thornton CA, Sheldon IM. Signal transducer and activator of transcription-3 licenses Toll-like receptor 4-dependent interleukin (IL)-6 and IL-8 production via IL-6 receptor-positive feedback in endometrial cells. Mucosal Immunol (2016) 9(5):1125-36. doi: 10.1038/mi.2015.131

48. Roilides E, Katsifa H, Tsaparidou S, Stergiopoulou T, Panteliadis C, Walsh TJ. Interleukin 10 suppresses phagocytic and antihyphal activities of human neutrophils. Cytokine (2000) 12(4):379-87. doi: 10.1111/j.1574-695X.1996. tb00084.x

49. Adhikary G, Sun Y, Pearlman E. C-Jun NH2 terminal kinase (JNK) is an essential mediator of Toll-like receptor 2-induced corneal inflammation. J Leukoc Biol (2008) 83(4):991-7. doi: 10.1189/jlb.1107783

50. Kaufmann TB, Drillich M, Tenhagen BA, Forderung D, Heuwieser W. Prevalence of bovine subclinical endometritis $4 \mathrm{~h}$ after insemination and its effects on first service conception rate. Theriogenology (2008) 71(2):385-91. doi: 10.1016/j.theriogenology.2008.08.005

51. Chu PY, Lee CS, Wright PJ. Degeneration and apoptosis of endometrial cells in the bitch. Theriogenology (2006) 6-7:1545-9. doi: 10.1016/j.theriogenology.2006.01.018

52. Senbanjo LT, Chellaiah MA. CD44: a multifunctional cell surface adhesion receptor is a regulator of progression and metastasis of cancer cells. Front Cell
Dev Biol (2017) 7:18. eCollection 2017. doi: 10.3389/fcell.2017.00018. eCollection 2017

53. Thorne RF, Legg JW, Isacke CM. The role of the CD44 transmembrane and cytoplasmic domains in coordinating adhesive and signalling events. J Cell Sci (2004) 117(Pt 3):373-80. doi: 10.1242/jcs.00954

54. Tienthai P, Yokoo M, Kimura N, Heldin P, Sato E, Rodriguez-Martinez H. Immunohistochemical localization and expression of the hyaluronan receptor CD44 in the epithelium of the pig oviduct during oestrus. Reproduction (2003) 125(1):119-32. doi: 10.1530/rep.0.1250119

55. Abe T, Fukuhara T, Wen X, Ninomiya A, Moriishi K, Maehara Y, et al. CD44 participates in the IP-10 induction in cells replicating HCV RNA through an interaction with TLR2 and hyaluronan. J Virol (2012) 86(11):6159-70. doi: 10.1128/JVI.06872-11

56. Shimada M, Yanai Y, Okazaki T, Noma N, Kawashima I, Mori T, et al. Hyaluronan fragments generated by sperm-secreted hyaluronidase stimulate cytokine/chemokine production via the TLR2 and TLR4 pathway in cumulus cells of ovulated COCs, which may enhance fertilization. Development (2008) 135(11):2001-11. doi: 10.1242/dev.020461

57. Troedsson MH, Liu IK, Crabo BG. Sperm transport and survival in the mare. Theriogenology (1998) 49(5):905-15. doi: 10.1016/s0093-691x(98)00185-x

Conflict of Interest: The authors declare that the research was conducted in the absence of any commercial or financial relationships that could be construed as a potential conflict of interest.

Copyright (c) 2021 Elesh, Marey, Zinnah, Akthar, Kawai, Naim, Goda, Rawash, Sasaki, Shimada and Miyamoto. This is an open-access article distributed under the terms of the Creative Commons Attribution License (CC BY). The use, distribution or reproduction in other forums is permitted, provided the original author(s) and the copyright owner(s) are credited and that the original publication in this journal is cited, in accordance with accepted academic practice. No use, distribution or reproduction is permitted which does not comply with these terms. 